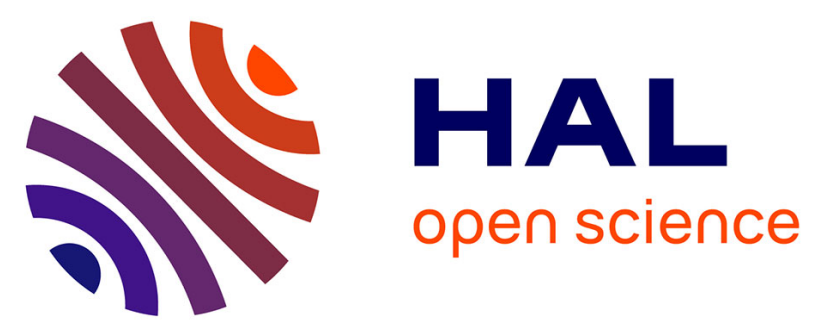

\title{
Marking the sacral landscape of a north Arabian oasis: a sixth-millennium BC monumental stone platform and surrounding burials
}

\author{
Olivia Munoz, Marianne Cotty, Guillaume Charloux, Charlène Bouchaud, \\ Hervé Monchot, Céline Marquaire, Antoine Zazzo, R. Crassard, Olivier \\ Brunet, Vanessa Boschloos, et al.
}

\section{To cite this version:}

Olivia Munoz, Marianne Cotty, Guillaume Charloux, Charlène Bouchaud, Hervé Monchot, et al.. Marking the sacral landscape of a north Arabian oasis: a sixth-millennium BC monumental stone platform and surrounding burials. Antiquity, 2020, 94 (375), pp.601-621. 10.15184/aqy.2020.81 . hal-02862815

\section{HAL Id: hal-02862815 https://hal.science/hal-02862815}

Submitted on 30 Sep 2020

HAL is a multi-disciplinary open access archive for the deposit and dissemination of scientific research documents, whether they are published or not. The documents may come from teaching and research institutions in France or abroad, or from public or private research centers.
L'archive ouverte pluridisciplinaire HAL, est destinée au dépôt et à la diffusion de documents scientifiques de niveau recherche, publiés ou non, émanant des établissements d'enseignement et de recherche français ou étrangers, des laboratoires publics ou privés. 
Munoz, O., Cotty, M., Charloux, G., Bouchaud, C., Monchot, H., Marquaire, C., Zazzo, A., Crassard, R., Brunet, O., Boschloos, V., \& al Malki, T. (2020). Marking the sacral landscape of a north Arabian oasis: A sixthmillennium BC monumental stone platform and surrounding burials. Antiquity, 94(375), 601-621.

https://doi.org/10.15184/aqy.2020.81

\title{
[For RESEARCH section]
}

\section{Marking the sacral landscape of a north Arabian oasis: a sixth-millennium BC monumental stone platform and surrounding burials}

Olivia Munoz ${ }^{1, *}$, Marianne Cotty ${ }^{2}$, Guillaume Charloux ${ }^{3}$, Charlène Bouchaud ${ }^{4}$, Hervé Monchot $^{5}$, Céline Marquaire ${ }^{6}$, Antoine Zazzo ${ }^{4}$, Rémy Crassard ${ }^{7}$, Olivier Brunet ${ }^{8}$, Vanessa Boschloos $^{9} \&$ Thamer al-Malki ${ }^{10}$

${ }^{1}$ Centre National de la Recherche Scientifique (CNRS), Archéologie et Sciences de l'Antiquité, France

${ }^{2}$ Musée du Louvre, Département de Antiquités Orientales, France

${ }^{3}$ Centre National de la Recherche Scientifique (CNRS), Orient et Méditerranée, France

${ }^{4}$ Centre National de la Recherche Scientifique (CNRS), Muséum national d'histoire naturelle, Archéozoologie \& Archéobotanique, France

${ }^{5}$ Labex Resmed, Paris Sorbonne Universités, France

${ }^{6}$ Université Paris 1 Panthéon-Sorbonne-UFR d'Archéologie, France

${ }^{7}$ Centre National de la Recherche Scientifique (CNRS), French Center for Archaeology and Social Sciences (CEFAS), Kuwait

${ }^{8}$ Archéologie et Sciences de l'Antiquité, Nanterre, France

${ }^{9}$ Department of Archaeology, Ghent University, Belgium

${ }^{10}$ Saudi Commission for Tourism and National Heritage, Riyadh, Saudi Arabia

*Author for correspondence ( $\square$ olivia.munoz@cnrs.fr)

Received: 6 March 2019; Revised: 2 September 2019; Accepted: 25 September 2019

$<$ LOCATION MAP, $6.5 \mathrm{~cm}$ colour, place to left of abstract and wrap around $>$

\begin{abstract}
Prehistoric stone structures are prominent and well-studied in the Levantine desert margins. In northern Arabia, however, such structures have received less attention. This article presents the results of investigations of a 35m-long stone platform, first constructed in the mid sixth millennium BC, overlooking the oasis of Dûmat al-Jandal in northern Saudi Arabia. Excavation of the platform has yielded bioarchaeological and cultural remains, along with evidence for several phases of construction and intermittent use down to the first millennium $B C$. Analysis of the platform and nearby tombs highlights the persistent funerary and ritual use of this area over millennia, illuminating nomadic pastoralist lifeways in prehistoric Arabia.
\end{abstract}

Keywords: Arabian Peninsula, Neolithic, Mid-Holocene, monumentality, funerary landscape, nomadic pastoralism

\section{Introduction}

Generally considered as territorial markers, clusters of stone structures - in particular cairns and enclosures or aligned stones visible on satellite imagery, such as the so-called desert kites - reveal dense and interrelated occupation across the Levant and the Arabian Peninsula during the Mid-Holocene (c. 6.5k-2.8k BC) (Steimer-Herbet 2004). This phenomenon also suggests that a pastoralist way of life spread along the desert margins for a distance of over $2000 \mathrm{~km}$ during this Mid-Holocene period of transition from the Late Neolithic to the Chalcolithic (Guagnin et al. 2017). As elsewhere in the world (e.g. Göbekli Tepe and Stonehenge; see Parker Pearson 2013; Schmidt 2015), the most exceptional of these megaliths can be considered as places for social gatherings and associated ceremonies. 
Munoz, O., Cotty, M., Charloux, G., Bouchaud, C., Monchot, H., Marquaire, C., Zazzo, A., Crassard, R., Brunet, O., Boschloos, V., \& al Malki, T. (2020). Marking the sacral landscape of a north Arabian oasis: A sixthmillennium BC monumental stone platform and surrounding burials. Antiquity, 94(375), 601-621.

https://doi.org/10.15184/aqy.2020.81

Unlike in the southern Levant, prehistoric stone monuments in northern Saudi Arabia remain largely unexplored (Nayeem 1990; Fujii 2013; Crassard et al. 2015; Kennedy 2017). Although the mid-Holocene in northern Arabia has been much discussed (e.g. Groucutt \& Petraglia 2012; Crassard \& Drechsler 2013; Magee 2014), research has focused predominantly on lithic technology, rock art, palaeoclimatic and palaeoenvironmental conditions and infrequently encountered stratified seasonal campsites (e.g. Crassard et al. 2013; Gebel 2013, 2016; Jennings et al. 2013; Guagnin et al. 2017, 2018, 2020; Scerri et al. 2018; Zielhofer et al. 2018). The lack of focus on stone monuments is due mostly to the relatively late exploration of the region, the first surveys dating to the 1970s (Adams et al. 1977; Parr et al. 1978; Zarins et al. 1979). Furthermore, it is still difficult to date these structures since so few have been excavated.

To gain an overview of such a large-scale phenomenon across the Near East, we must understand how these stone structures, particularly the largest examples, developed in the arid margins. In this regard, the recent excavation of a late Mid-Holocene stone platform in the oasis of Dûmat al-Jandal in Jawf Province, Saudi Arabia, constitutes a major contribution to our understanding of the origin, nature and evolution of human occupation in the region. Detailed analysis of the site, combined with dating of nearby tombs, confirms that ceremonial activity took place at this northern Arabian oasis from the second half of the sixth millennium $\mathrm{BC}$ onwards.

\section{Architectural and stratigraphic sequence of the platform}

Best known for its role as a crossroads on the caravan routes of antiquity, the oasis of Dûmat al-Jandal, is located in a desert region that today receives no more than $50 \mathrm{~mm}$ of annual precipitation (Charloux 2018) (Figure 1). The oasis is situated in the lower part of a vast graben (steep-sided valley) at 580-680m asl, supplied with water by several small wadis and, especially, by a now overexploited source of fossil groundwater (Charloux et al. 2018).

$<$ FIGURE $1,13.5 \mathrm{~cm}$ colour $>$

The study area, in the western part of the oasis, is located on the southern side of the mouth of two small wadis filled with Quaternary alluvial and aeolian deposits. A vast limestone plateau (of the geological formation known as the Qasr Member of the Jauf formation; Wallace et al. 1997), stands some 50m above the valley (average altitude $665 \mathrm{~m}$ ), extending over $2.7 \mathrm{~km}$ at this location. Most of the archaeological remains are concentrated on a $700 \mathrm{~m}$-long natural tongue-shaped promontory on the plateau's northern flank, which belongs to the geological formation known as the Hammamiyat Member of the Jauf formation. Archaeological investigations between 2010 and 2017 have concentrated on a 40ha fortified sector in this area, but also on the systematic recording of archaeological remains within the oasis and in an area approximately $30 \mathrm{~km}$ around it (Charloux 2018) (Figures 1-2).

$<$ FIGURE 2, 20cm colour, place landscape $>$

In 2014-2016, we excavated a monumental stone structure (L2200 on Figures 1-2) on the southern edge of the promontory. It is trapezoidal in shape, taking the form of a platform oriented on an east-west axis (Figures 3-4). The structure survives to a maximum height of $0.7 \mathrm{~m}$ and is $34.6 \mathrm{~m}$ long. It is $14.6 \mathrm{~m}$ wide on its eastern side and $3.4 \mathrm{~m}$ wide on its western side. The eastern part of the monument has two rectangular niches, each approximately $1 \mathrm{~m}$ wide and $2 \mathrm{~m}$ long, symmetrically arranged on either side of the structure's longitudinal axis. The platform is bounded by dry-stone walls and entirely filled with rubble.

$<$ FIGURE 3, $13.5 \mathrm{~cm}$ colour $>$

$<$ FIGURE 4, 20cm colour, place landscape $>$ 
Munoz, O., Cotty, M., Charloux, G., Bouchaud, C., Monchot, H., Marquaire, C., Zazzo, A., Crassard, R., Brunet, O., Boschloos, V., \& al Malki, T. (2020). Marking the sacral landscape of a north Arabian oasis: A sixthmillennium BC monumental stone platform and surrounding burials. Antiquity, 94(375), 601-621.

https://doi.org/10.15184/aqy.2020.81

The platform was built in three phases, followed by an abandonment phase and a later, monumental third- to second-century BC rampart. Four deposits were assigned to the Late Neolithic architectural sequence.

The initial platform (phase I) was built on a west/north-west to east/south-east axis, corresponding to the winter sunrise and sunset. It is trapezoidal in shape, and measures $20.6 \mathrm{~m}$ in length; its width is $2.7 \mathrm{~m}$ at its western end and $8.8 \mathrm{~m}$ at its eastern end. All the phase 1 walls are connected, indicating a single phase of construction. Built either directly on the bedrock or on an indurated marl-limestone layer, the walls comprise rough dry-stone courses of irregular flat stones, on average about $0.20 \times 0.30 \mathrm{~m}$, and $50-100 \mathrm{~mm}$ thick. The pressure exerted by the stone infilling created an overhang on the south-eastern side of the platform; to prevent the wall from collapsing outwards, large irregular blocks were added to support it. The eastern facade of the platform has a central niche (niche 1) measuring $1 \times 2.15 \mathrm{~m}$ (Figures $4-5$ ). On the base of this niche, four stones were set vertically in the white substrate, suggesting the presence of a wooden post.

\section{$<$ FIGURE 5, $13.5 \mathrm{~cm}$ colour $>$}

In Phase II, the structure was extended $8.4 \mathrm{~m}$ towards the north-west, and a second niche installed (niche 2) abutting the northern wall of phase I (Figures 3-4). Niche 2, measuring 2.30 $\times 1.10 \mathrm{~m}$, resembles niche 1 in size, and its layout suggests an attempt at symmetry on either side of the longitudinal axis of the platform. Phase III is an additional extension of $5.30 \mathrm{~m}$ to the west. The same building techniques were used in this phase, including a coarsely faced wall with rubble infill.

Phase IV corresponds to the abandonment of the structure, attested by the collapse of several walls, such as the western wall and the north-eastern corner of the platform. Phase $\mathrm{Va}$ represents the construction of the Hellenistic period (third to second centuries BC) rampart. Surviving to a height of up to $2.65 \mathrm{~m}$, this rampart rests partly on the collapsed north-eastern corner of the platform. A layer of green marl between the platform's demolition layer and the first foundation of the rampart indicates that the ground was levelled before its construction. Phase $\mathrm{Vb}$ is characterised by the installation of two first-millennium $\mathrm{BC}$ hearths on the abandoned platform (see Figure 6 and the online supplementary material (OSM) 1).

$<$ FIGURE 6, 20cm greyscale, place landscape $>$

\section{Archaeological deposits on the platform}

Deposit 1 was discovered within the stone infill of the phase 1 platform. It is characterised by two concentrations of human bones in a secondary position, representing at least one individual aged over 15 years (see OSM 2). Radiocarbon dating of bioapatite indicates that this individual, and probably the associated deposit, dates to the end of the sixth millennium BC (Figure 6 \& OSM 1). Two artefacts were associated with this deposit: a white limestone bead and a perforated marine gastropod (Pterygia crenulata) shell (Figure 7A \& B).

\section{$<$ FIGURE $7,13.5 \mathrm{~cm}$ colour $>$}

Sealed beneath aeolian sandy layers in niche 1, deposit 2 (phases I-IV) contains evidence of human occupation. An ashy layer located at the base of the niche 1 was sampled (50 litres) for archaeobotanical analysis. It yielded a moderate quantity of small charcoal fragments, 56 of which have been analysed. Three taxa have been identified (Figure 8A-B \& OSM 3): white acacia (Fadherbia albida, 32 fragments), tamarisk (Tamarix sp., 17 fragments) and the Amaranthaceae family (three fragments). Growing to $30 \mathrm{~m}$ in height, white acacia (Figure 8A1) is native to the Sudano-Zambezian floristic region (Neumann et al. 2001: 318) and is rarely recorded in Arabia today in its wild form (Jagiella \& Kürschner 1987: 20-34). The 
Munoz, O., Cotty, M., Charloux, G., Bouchaud, C., Monchot, H., Marquaire, C., Zazzo, A., Crassard, R., Brunet, O., Boschloos, V., \& al Malki, T. (2020). Marking the sacral landscape of a north Arabian oasis: A sixthmillennium BC monumental stone platform and surrounding burials. Antiquity, 94(375), 601-621.

https://doi.org/10.15184/aqy.2020.81

Amaranthaceae family includes several shrub species with similar anatomical traits (Figure 8A2). Haloxylon salicornicum is the most widespread, found today in the sandy and rocky plains of north-western Arabia (Kürschner \& Neef 2011). Tamarix sp. typically grows along watercourses in desert areas (Figure 8A3), Tamarix aphylla being the most common species in north-western Arabia (Miller \& Cope 1996). A fragment of tamarisk (Tamarix sp.) from this charcoal layer was radiocarbon-dated to the middle of the sixth millennium BC (Figure $6 \&$ OSM 1).

\section{$<$ FIGURE $8,13.5 \mathrm{~cm}$ greyscale $>$}

Deposit 2 in niche 1 also yielded a faunal assemblage $(n=68)$, comprising 45 fragments of bovid (Bos sp.) maxillary teeth (probably the teeth of a single adult individual), the burnt distal extremity of an ovicaprine metapodial, and 22 unidentified fragments (Figure 8C \& OSM 3). Probable exposure to water and sand has resulted in heavy weathering and abrasion of all tooth fragments - as also observed in faunal assemblages from Jabal Oraf 2 and Alshabah in northern Saudi Arabia (Guagnin et al. 2017; Scerri et al. 2018).

The lithics (Figure 7G) found in deposit 2 mostly consist of small unretouched flakes from two or three different cores. Dating broadly to the Neolithic, these lithics are made of carefully selected raw material, mainly coloured flints and jaspoid cherts, as attested on numerous MidHolocene sites across the Arabian Peninsula (e.g. Crassard et al. 2013).

Deposit 2 in niche 1 also yielded two bone artefacts: a $110 \mathrm{~mm}$-long pin and a 55mm-long naviform object of unknown function (Figure 7D-E). Finally, a small cut and polished conical stone mearing approximately $200 \times 200 \mathrm{~mm}$ (Figure $7 \mathrm{~F}$ ) was found in deposit 2. Possibly a small grinding pestle, it resembles an artefact recently discovered in Rajajil in north-western Arabia (Gebel 2016: 91, fig. 8).

Evidence of human activity in deposit 3 (phases II-IV) in niche 2 is limited to a few flint flakes and cores, along with a fragment of good-quality chalcedony unknown from the vicinity.

Deposit 4 (phases II-IV) consists of artefacts found disturbed in a recent looting pit dug against the eastern wall of the platform (D4 on Figure 4). Excavation of the pit yielded fragmented and disarticulated human bones $(n=2647)$ representing at least five individuals (OSM 2), as well as 13 stone and shell beads (Figure 7C \& OSM 4). These comprise two cylindrical shell beads, three cylindrical stone beads, three flat beads of whitish stone, and five carnelian beads of either local or Egyptian origin (OSM 4-5).This material was mixed with a loose, orange-brown sand, including many large, irregular stones, similar to those of the platform. A radiocarbon assay of a human bone fragment (bioapatite) indicates that the deposit from which the artefacts derive dates to the second half of the fourth millennium BC (Figure 6 \& OSM 1). Deposit 4 also yielded a faunal assemblage $(\mathrm{n}=75)$ comprising 48 bovid (Bos sp.) tooth fragments, one burnt distal epiphysis of a caprine metapodial, seven fragments from a large herbivore and 19 unidentified bones (Figure 8).

\section{Discussion}

Structurally, the original platform (phase I) appears to have been modified in two successive phases (phases II and III) before it was abandoned, although it is not possible to determine how long the platform was in use. The date obtained on the tamarisk charcoal sample at the base of niche 1 indicates activity as early as the mid sixth millennium $\mathrm{BC}$, followed by a late sixthmillennium BC date for human bone in deposit 1 (Figure 6 \& Table S1 in OSM 1). Deposit 4 dates to the second half of the fourth millennium BC, but, as it is disturbed, it cannot be attributed more precisely than to a period between phases II and IV. The monument was certainly in use during the second half of the sixth millennium $\mathrm{BC}$, but a longer period, until the fourth millennium $\mathrm{BC}$, cannot be discounted. The date of the platform's abandonment 
Munoz, O., Cotty, M., Charloux, G., Bouchaud, C., Monchot, H., Marquaire, C., Zazzo, A., Crassard, R., Brunet, O., Boschloos, V., \& al Malki, T. (2020). Marking the sacral landscape of a north Arabian oasis: A sixthmillennium BC monumental stone platform and surrounding burials. Antiquity, 94(375), 601-621.

https://doi.org/10.15184/aqy.2020.81

remains uncertain, with only a terminus ante quem provided by the first-millennium $\mathrm{BC}$ construction of the rampart and installation of surface hearths of phase V.

Two categories of archaeological deposit illuminate the function of this platform:

- Funerary deposits (deposits 1 and 4) attest to the repeated use of the area for mortuary activity over two millennia.

- Primary deposits (deposits 2 and 3 ) in the niches, including artefacts and bioarchaeological remains, potentially related to the symbolic use of the space or structure.

The platform's dimensions and evidence of longevity and maintenance all indicate that it should be considered as a monument (following Osborne 2014). In addition to the disposal and commemoration of the dead, the platform's east-west alignment with the winter solstice reveals a knowledge of astronomical phenomena that is common to other structures in Arabia and elsewhere (Steimer-Herbet 2004). The platform constituted a ceremonial space for social and ritual activities, providing a material anchor for social memory and identity construction (Scarre 2011, 2018), as well as a territorial marker, for the mobile pastoralists of the area.

Although the Dûmat platform is unique in its proportions, similar stone structures from the southern Levant and the central and southern Arabian Peninsula connect it to a broader cultural tradition. Probably built during the Mid-Holocene (Neolithic to Early Bronze Age) and spanning an area of over $2000 \mathrm{~km}$ from north to south, these structures vary in length from 6$30 \mathrm{~m}$, and have many different shapes, including circular, rectangular and trapezoidal (Figure 9). Most platforms are interpreted as ceremonial structures, collective spaces linked to pastoralism, or cenotaphs (e.g. Zarins et al. 1979; Haiman 1996; al-Khalifa et al. 2001; McCorriston et al. 2012, 2014; Abu-Azizeh et al. 2014: 167-68; Gebel 2016: 87-91; Schiettecatte et al. 2017). In addition, these platforms appear to be systematically linked to a religious or a funerary function.

$<$ FIGURE 9, $13.5 \mathrm{~cm}$ greyscale $>$

The presence of a platform at Dûmat al-Jandal and the high density of burials in its vicinity (comprising 66 structures; Figure 1) are also strongly suggestive of prehistoric occupation in or close to the oasis. Predominantly located at the highest points of the landscape and overlooking the wadis, as is frequent in Arabia (e.g. Steimer-Herbet 2004; Steimer-Herbet et al. 2006; Cleuziou \& Munoz 2007; Giraud 2010), most of the hundreds of (systematically looted and often reused) funerary structures in the Southern Jawf have similar circular shapes (cairns). The assemblages recovered from these tombs are relatively standard, comprising simple elements of adornment (e.g. limestone and carnelian beads, and pierced shells), and, less frequently, metal artefacts (e.g. weapons and tools) or scarab-shaped seals in the most recent tombs (see OSM 4).

Radiocarbon dating was undertaken on human bone from these cairns, revealing at least four periods of use (Figure $6 \&$ OSM 1):

1) Fifth millennium BC, between 4685 and 4075 BC.

2) Second half of the fourth millennium $B C$ to the second half of the third millennium BC (3485-2345 BC).

3) Mid-second millennium BC (between 1610 and 1435 BC).

4) First millennium $B C$ to the beginning of the first millennium $A D$ (between $768 \mathrm{BC}$ and $\mathrm{AD} 55$ ). 
Munoz, O., Cotty, M., Charloux, G., Bouchaud, C., Monchot, H., Marquaire, C., Zazzo, A., Crassard, R., Brunet, O., Boschloos, V., \& al Malki, T. (2020). Marking the sacral landscape of a north Arabian oasis: A sixthmillennium BC monumental stone platform and surrounding burials. Antiquity, 94(375), 601-621.

https://doi.org/10.15184/aqy.2020.81

One radiocarbon date obtained on a charcoal sample from a cairn burial excavated on the promontory (Tomb L2204, SD31) suggests that it was used at the very end of the first millennium $\mathrm{BC}$ to the beginning of the first millennium $\mathrm{AD}$, although the material found in the tomb could suggest an earlier date from the first half of the first millennium BC (Figure 10; see also OSM 1, $4 \& 5$ ). Continuity in the use of the local funerary landscape is also noted for later periods, with evidence of a Nabataean-Roman necropolis inside the oasis (Figure 6; OSM 1; also see Charloux et al. 2014).

\section{$<$ FIGURE $10,13.5 \mathrm{~cm}$ colour $>$}

The sequence recorded at Dûmat al-Jandal provides four major lines of evidence. First, the region was repeatedly occupied, from at least the sixth millennium $\mathrm{BC}$, but with hiatuses during the first half of the fourth millennium $\mathrm{BC}$ and in the second millennium $\mathrm{BC}$, represented only by tomb TB1088, 15km north-west of Dûmat al-Jandal (Figure 1). Second, the sequence of stone cairns seems to confirm continuity in funerary customs from the fifth millennium $\mathrm{BC}$ onwards, potentially suggesting a continuous nomadic pastoralist way of life. Third, the platform is, in the current state of research, the oldest structure in the oasis. Fourth, several tombs may have been contemporaneous with the use of the platform if we envisage a longterm use, although it is possible that the tombs are more recent and not related to the platform but forming part of the landscape of the fifth to fourth millennia BC.

\section{Mid-Holocene occupation in the region}

After a relatively humid phase lasting from the Early Holocene (8000-6500 BC) to the MidHolocene (c. 5000 BC) (Engel et al. 2017; Zielhofer et al. 2018), it seems that climatic variations in northern Arabia led to aridity in the lowlands around $3000 \mathrm{BC}$. Palynological research in Taymā' in north-western Saudi Arabia, for example, shows a progressive decline from semi-arid steppe to the arid/hyper-arid desert-like landscape that we know today (Dinies et al. 2016). Several palaeolakes dried up during this period of aridification, for example in the southern Jawf and the Nefud Desert (Crassard et al. 2013; Loreto 2013; Guagnin et al. 2018). A perennial lake at Taymā' contracted gradually from $6000 \mathrm{BC}$ onwards, disappearing by 2000 BC (Wellbrock et al. 2018). Other sites, such as Rasif (also in north-western Saudi Arabia), however, continued to be fed by aquifers (Gebel \& Wellbrock 2019). The transition to more arid conditions during the sixth-fourth millennia $\mathrm{BC}$ caused the human population to contract as nomadic pastoralism developed. The lack of reliable data on northern Arabian Early and Mid-Holocene annual precipitation, and the scarcity of stratified archaeological contexts, however, preclude a fuller understanding of this long-term process. Following the Late Neolithic settlements known to have existed in north-eastern Jordan and northern Saudi Arabia (e.g. Fujii 2010; Rollefson et al. 2014; Gebel 2016), traces of permanent occupation disappeared in the late sixth to fifth millennia $\mathrm{BC}$ in these regions, possibly to be replaced by seasonal camps (Guagnin et al. 2018; Scerri et al. 2018). Thousands of stone cairns found across northern Arabia attest to the presence of post-sixth-millennium BC mobile pastoralist populations, who gathered in collective spaces, shrines or funerary areas with standing stones. These sites fulfilled important collective functions, for example at Rajajil (Zarins et al. 1979; Gebel 2013, 2016) and further afield, for example, at Rizqeh (e.g. Kirkbride 1969).

In this regard, the site of Rasif is of primary importance, as it provides evidence for the evolution of water management and lifeways in a 'proto-oasis' during the Late NeolithicChalcolithic transition (Gebel 2016; Zielhofer et al. 2018; Gebel \& Wellbrock 2019). At Taymā', fig (Ficus carica type) pollen and seeds dating to $c$. 4800-4300 BC suggest a Late Chalcolithic-Early Bronze Age permanent occupation and an oasian way of life, a chronology also supported by the archaeological data (Dinies et al. 2016; Hausleiter et al. 2018). 
Considering this overall sequence, it is necessary to question the role and position of the Dûmat al-Jandal oasis during the Chalcolithic-Early Bronze Age periods, in particular the problematic fifth to third millennia BC. The platform (L2200) was built in the Late Neolithic, possibly by mobile pastoralists, while stone structures, including tombs as well as the platform, attest to a recurrent human presence from the second half of the sixth millennium BC. There is little doubt that Dûmat al-Jandal was a well-watered place, and therefore a refuge for human populations, throughout its history; a large $5 \times 8 \mathrm{~km}$ basin ranging in depth from 50 to $100 \mathrm{~m}$, the oasis was naturally supplied with water from small wadis and abundant springs (Charloux et al. 2018). Although the prehistoric landscape cannot be reconstructed without detailed hydrological and palaeoclimatic analyses, the Dûmat basin certainly contained a palaeolake during the early Mid-Holocene. It may therefore be that this place was only partly affected by the increasing aridity of the later Mid-Holocene.

The long-term human presence at Dûmat al-Jandal — as highlighted by the monumental platform and surrounding funerary landscape - can be explained by the presence of perennial water resources. By overtly marking the landscape with their tombs, the groups frequenting the area may have materialised their presence and asserted their rights and inheritance over these resources (see Parker Pearson 1999). It remains to be ascertained, however, whether the Chalcolithic-Early Bronze Age pastoral nomadic groups, characterised by their burial cairns, occupied a semi-permanent site in the early oasis, as seen at nearby Rasif, or whether they lived alongside populations already permanently settled in the oasis. The second hypothesis would correspond to the indigenous way of life known from the first millennium $\mathrm{BC}$ to the nineteenth century AD in the hyper-arid context at Dûmat al-Jandal (Veccia Vaglieri 2012). Both hypotheses would be compatible with an early oasis in the fifth millennium BC, as at Taymâ' (Hausleiter et al. 2018) or at Rasif (Gebel \& Wellbrock 2019). At the latter site, local environmental conditions precluded the development of a full oasis economy, such as at Dûmat al-Jandal. Further research should provide greater insights into the subsistence economy of protohistoric Dûmat al-Jandal. Our results suggest that monumental structures and burials in northern Arabia marked the landscape over millennia, anchoring nomadic pastoralists to a significant place, not only for its environmental advantages but also for its significance to the community, a recurrent theme in much pre-and protohistoric archaeology.

\section{Acknowledgements}

This study forms part of a Saudi-Italian-French archaeological project at Dûmat al-Jandal, directed by Guillaume Charloux (CNRS) and Romolo Loreto (University of Naples l'Orientale). It is supported by several French (CNRS, Ministry of Foreign Affairs, French Embassy in Riyadh), Italian (Ministry of Foreign Affairs, l'Orientale) and Saudi (Saudi Commission for Tourism and National Heritage) institutions. This research is also funded by the Labex RESMED (ANR-10-LABX-72), under the investment program ANR-11-IDEX0004-02. The authors wish to thank Olivier Trombet (Labex BCDiv, UMR 7209) and Anaïs Marrast (Muséum national d'Histoire naturelle, UMR 7209) for their expertise.

\section{Supplementary material}

To view supplementary material for this article, please visit XXXX 
Munoz, O., Cotty, M., Charloux, G., Bouchaud, C., Monchot, H., Marquaire, C., Zazzo, A., Crassard, R., Brunet, O., Boschloos, V., \& al Malki, T. (2020). Marking the sacral landscape of a north Arabian oasis: A sixthmillennium BC monumental stone platform and surrounding burials. Antiquity, 94(375), 601-621.

https://doi.org/10.15184/aqy.2020.81

\section{References}

ABU-AZizeH, W., F. ABUdAnah, S. Twaissi \& A. AL-SalameEn. 2014. Variability within consistency: cairns and funerary practices of the Late Neolithic/Early Chalcolithic in Al-Thulaythuwat area, southern Jordan. Levant 46: 161-85. https://doi.org/10.1179/0075891414Z.00000000040

ADAMS, R., P.J. PARR, M. IBRAHIM \& A.S. MUGHANNUM. 1977. Saudi Arabian archaeological reconnaissance1976: preliminary report on the first phase of the comprehensive archaeological survey program. Atlal 1:2140.

AL-Khalifa, K.A., S. AL-HawaiJi, N. AL-Daniawi, A. AL-EISA, S. AL-Helwa, S. AL-RaIYAN \& A. AL-Shairi. 2001. Preliminary report on the survey and documentation of archaeological sites (Yabrin Oasis), 1993. Atlal 16: 91-95.

BRONK RAMSEY, C. 2009. Bayesian analysis of radiocarbon dates. Radiocarbon 51: 337-60. https://doi.org/10.1017/S0033822200033865

CHARLOUX, G. 2018. Rythmes et modalités du peuplement d'une oasis du nord-ouest de l'Arabie: Sept campagnes (2010-2017) sur le site de Dûmat al-Jandal. Comptes-rendus de l'Académie des Inscriptions et Belles-Lettres 2018 (janvier): 11-46.

Charloux, G., M. CotTy \& A. ThOMAS. 2014. Nabataean or not? The ancient necropolis of Dumat. First stage: a reassessment of al-Dayel's excavations. Arabian Archaeology and Epigraphy 25: 186-213. https://doi.org/10.1111/aae.12044

Charloux, G., P. Courbon, T. Thomas \& O. Testa. 2018. Mapping an ancient qanat system in a northern Arabian urbanized oasis: results of GIS analysis and archaeological survey. Water History 10: 31-51. https://doi.org/10.1007/s12685-017-0203-4

CleuZiou, S. \& O. MuNOZ. 2007. Les morts en société : une interprétation des sépultures collectives d'Oman à l'âge du Bronze, in L. Baray, P. Brun \& A. Testart (ed.) Pratiques funéraires et sociétés: nouvelles approches en archéologie et en anthropologie sociale: 293-317. Dijon: Presses universitaires de Dijon.

CRASSARD, R. \& P. DRECHSLER. 2013. Towards new paradigms: multiple pathways for the Arabian Neolithic. Arabian Archaeology and Epigraphy 24: 3-8. https://doi.org/10.1111/aae.12021

Crassard, R., M.D. Petraglia, A.G. Parker, A. Parton \& R.G. Roberts. 2013. Beyond the Levant: first evidence of a Pre-Pottery Neolithic incursion into the Nefud Desert, Saudi Arabia. PLOSOne 8: e68061. https://doi.org/10.1371/journal.pone.0068061

CRASSARD, R. et al. 2015. Addressing the desert kites phenomenon and its global range through a multi-proxy approach. Journal of Archaeological Method and Theory 22: 1093-1121. https://doi.org/10.1007/s10816-0149218-7

Dinies, M., R. NEEF, B. PlesSEN \& H. KÜRSCHNER. 2016. Holocene vegetation, climate, land use and plant cultivation in the Tayma Region, north-western Arabia, in M. Luciani (ed.) The archaeology of North Arabia: oases and landscapes. Proceedings of the International Congress held at the University of Vienna, 5-8 December, 2013: 57-78. Vienna: Austrian Academy of Science.

Engel, M., A. Matter, A.G. Parker, A. Parton, M.D. Petraglia, G.W. Preston \& F. Preusser. 2017. Lakes or wetlands? A comment on 'The Middle Holocene climatic records from Arabia: reassessing lacustrine environments, shift of ITCZ in Arabian Sea, and impacts of the southwest Indian and African monsoons' by Enzel et al. Global and Planetary Change 148: 258-67. https://doi.org/10.1016/j.gloplacha.2016.11.001

FUJII, S. 2010. Domestication of runoff surface water: current evidence and new perspectives from the Jafr Pastoral Neolithic. Neo-Lithics 2: 14-33.

- 2013. Jawf/Tabuk Archaeological Project (JTAP): a brief report of the second field season, 2013. Field report submitted to the Saudi Commission for Tourism \& National Heritage, Saudi Arabia.

GEBEL, H.G.K. 2013. Arabia's fifth-millennium BCE pastoral well cultures: hypotheses on the origins of oasis life. Proceedings of the Seminar for Arabian Studies 43: 111-26.

- 2016. The socio-hydraulic foundations of oasis life in NW Arabia: the $5^{\text {th }}$ millennium BCE shepherd environs of Rajajil, Rasif and Qulban Beni Murra, in M. Luciani (ed.) The archaeology of North Arabia: oases and landscapes. Proceedings of the International Congress held at the University of Vienna, 5-8 December, 2013: 79-114. Vienna: Austrian Academy of Sciences. 
Munoz, O., Cotty, M., Charloux, G., Bouchaud, C., Monchot, H., Marquaire, C., Zazzo, A., Crassard, R., Brunet, O., Boschloos, V., \& al Malki, T. (2020). Marking the sacral landscape of a north Arabian oasis: A sixthmillennium BC monumental stone platform and surrounding burials. Antiquity, 94(375), 601-621.

\section{https://doi.org/10.15184/aqy.2020.81}

GeBEL, H.G.K. \& K. WELLBROCK. 2019. Hydraulic cultures and hydrology under climatic change: North Arabian Mid-Holocene Pastoral and proto-oasis land use, in E. Chistos (ed.) Climate changes in the Holocene: impacts and human adaptation: 247-70. Boca Raton (FL): Taylor \& Francis. https://doi.org/10.1201/978135126024412

GIRAUD, J. 2010. Early Bronze Age graves and graveyards in the eastern Ja'alan (Sultanate of Oman): an assessment of the social rules working in the funerary landscape, in L. Weeks (ed.) Death and burial in Arabia and beyond: multidisciplinary perspectives (British Archaeological Reports International series 2107): 71-84. Oxford: British Archaeological Reports.

Groucutt, H.S. \& M.D. Petraglia. 2012. The prehistory of the Arabian Peninsula: deserts, dispersals and demography. Evolutionary Anthropology: Issues, News, and Reviews 21: 113-25. https://doi.org/10.1002/evan.21308

Guagnin, M., C. Shipton, L. Martin \& M.D. Petraglia. 2017. The Neolithic site of Jebel Oraf 2, northern Saudi Arabia: first report of a directly dated site with faunal remains. Archaeological Research in Asia 9: 6367. https://doi.org/10.1016/j.ara.2017.02.001

Guagnin, M., C. Shipton, S. el-Dossary, F. Moussa, M. Stewart, F. Ott, A. Alsharekh \& M.D. PETRAGLIA. 2018. Rock art provides new evidence on the biogeography of kudu (Tragelaphus imberbis), wild dromedary, aurochs (Bos primigenius) and African wild ass (Equus africanus) in the early and Middle Holocene of north-western Arabia. Journal of Biogeography 45: 727-40. https://doi.org/10.1111/jbi.13165

Guagnin, M. et al. 2020. The Holocene humid period in the Nefud Desert: hunters and herders in the Jebel Oraf palaeolake basin, Saudi Arabia. Journal of Arid Environments 178. https://doi.org/10.1016/j.jaridenv.2020.104146

HaIMAN, M. 1996. Early Bronze Age IV settlement pattern of the Negev and Sinai Deserts: view from small marginal temporary sites. Bulletin of the American Schools of Oriental Research 303: 1-32. https://doi.org/10.2307/1357468

HAusleiter, A., R. EichmanN \& M. AL-NAJEM (ed.). 2018. Tayma $\bar{a}^{\prime}$ I: archaeological exploration, palaeoenvironment, cultural contacts. Oxford: Archaeopress.

JaGIELla, C. \& H. KÜRSCHNER. 1987. Atlas der Hölzer Saudi-Arabiens: die Holzanatomie der wichtigsten Bäume und Sträucher Arabiens mit einem Holzanatomischen Bestimmungsschlüssel. Wiesbaden: Ludwig Reichert.

Jennings, R., C. Shipton, A. Al-Omari, A. Alsharekh, R. Crassard, H.S. Groucutt \& M.D. Petraglia. 2013. Rock art landscapes beside the Jubbah palaeolake, Saudi Arabia. Antiquity 87: 666-83. https://doi.org/10.1017/S0003598X00049383

KENNEDY, D. 2017. 'Gates': a new archaeological site type in Saudi Arabia. Arabian Archaeology \& Epigraphy 28: 153-74. https://doi.org/10.1111/aae.12100

KIRKBRIDE, D. 1969. Ancient Arabian ancestor idols. Parts I and II: the discovery of the sanctuary at Rizqeh. Archaeology in the United Arab Emirates 22: 116-21 \& 188-95.

KÜRSCHNER, H. \& R. NeEF. 2011. A first synthesis of the flora and vegetation of the Tayma Oasis and surroundings (Saudi Arabia). Plant Diversity and Evolution 129: 27-58. https://doi.org/10.1127/18696155/2011/0129-0033

LORETO, R. 2013. The Saudi-Italian-French archaeological project at Dûmat al-Jandal, ancient Adummatu (Saudi Arabia). New Neolithic evidence from al-Jawf region: an outline of the historical development of Dûmat alJandal. Proceedings of the Seminar for Arabian Studies 43: 213-24.

MAGEE, P. 2014. The archaeology of prehistoric Arabia: adaptation and social formation from the Neolithic to the Iron Age. Cambridge: Cambridge University Press. https://doi.org/10.1017/CBO9781139016667

McCorriston, J., M. Harrower, L. Martin \& E.A. OChes. 2012. Cattle cults of the Arabian Neolithic and early territorial societies. American Anthropologist 114: 45-63. https://doi.org/10.1111/j.15481433.2011.01396.x

McCorriston, J., M. Harrower, T. Steimer-Herbet, K.W. Williams, S. MatthieW, M. Al-Hadhari, M. AL-KATHIRI, J.-F. SAliÈGE \& J. EverheART. 2014. Monuments and landscape of mobile pastoralists in Dhofar: the Arabian Human Social Dynamics (AHSD) project. Journal of Oman Studies 12: 117-43.

Miller, A.G. \& T.A. COPE. 1996. Flora of the Arabian Peninsula and Socotra, volume 1. Edinburgh: Edinburgh University Press. 
Munoz, O., Cotty, M., Charloux, G., Bouchaud, C., Monchot, H., Marquaire, C., Zazzo, A., Crassard, R., Brunet, O., Boschloos, V., \& al Malki, T. (2020). Marking the sacral landscape of a north Arabian oasis: A sixthmillennium BC monumental stone platform and surrounding burials. Antiquity, 94(375), 601-621.

https://doi.org/10.15184/aqy.2020.81

NaYeEm, M.A. 1990. Prehistory and protohistory of the Arabian Peninsula, volume. 1: Saudi Arabia. Hyderabad: Hyderabad Publishers.

Neumann, K., W. Schoch, P. DÉTIENne \& F.H. SchweIngruber. 2001. Woods of the Sahara and the Sahel: an anatomical atlas. Bern: Paul Haupt.

OsbORNE, J.F. 2014. Monuments and monumentality, in J.F. Osborne (ed.) Approching monumentality in archaeology: 1-19. Albany: State University of New York Press.

PARKer PeARSON, M. 1999. The archaeology of death and burial. Stroud: Sutton.

- 2013. Researching Stonehenge: theories past and present. Archaeology international 16: 72-83. https://doi.org/10.5334/ai.1601

Parr, P.J., J. Zarins, M. Ibrahim, J. Waechter, A. Garrard, C. Clarke, M. Bidmeade \& H. Badr. 1978. Preliminary report on the second phase of the Northern Province Survey 1397/1977. Atlal 2: 29-51.

REIMER, P.J. et al. 2013. IntCal13 and Marine13 radiocarbon age calibration curves 0-50 000 years cal BP. Radiocarbon 55: 1869-87. https://doi.org/10.2458/azu_js_rc.55.16947

Rollefson, G., Y. Rowan \& A. Wasse. 2014. The late Neolithic colonization of the Eastern Badia of Jordan. Levant 46: 285-301. https://doi.org/10.1179/0075891414Z.00000000046

SCARRE, C. 2011. Monumentality, in T. Insoll (ed.) The Oxford handbook of the archaeology of ritual and religion: 9-23. Oxford: Oxford University Press. https://doi.org/10.1093/oxfordhb/9780199232444.013.0002

- 2018. Mounds and monumentality in Neolithic Europe, in A. Brysbaert, V. Klinkenberg, A. Gutierrez GarciaM, \& I. Vikatou (ed.) Constructing monuments, perceiving monumentality \& the economics of building: 4963. Leiden: Sidestone.

SCERRI, E. et al. 2018. Neolithic pastoralism in marginal environments during the Holocene Wet Phase, northern Saudi Arabia. Antiquity 92: 1180-94. https://doi.org/10.15184/aqy.2018.108

Schiettecatte, J., A. ChevalieR, A. AL-HAmmad \& S. TzORTZIs. 2017. Preliminary report: sixth season of the Saudi-French mission in al-Kharj, Province of Riyadh, 14 November-9 December 2016 (CNRS-UMR8167). Available at: https://halshs.archives-ouvertes.fr/halshs-01678561 (accessed 7 April 2020).

SCHMIDT, K. 2015. Le premier temple: Göbekli Tepe. Paris: CNRS.

SteIMER-Herbet, T. 2004. Classification des sépultures à superstructure lithique dans le Levant et l'Arabie occidentale (IVè-IIIè millénaires av. J.C.) (British Archaeological Reports International series 1246). Oxford: Archaeopress.

Steimer-Herbet, T., G. DAVtian \& F. BRAEMER. 2006. Pastoralists' tombs and settlement patterns in Wadi Wash'ah during the Bronze Age (Hadramawt, Yemen). Proceedings of the Seminar for Arabian Studies 36: $257-65$.

Veccia VAglieRI, L. 2012. Dūmat al-Ḍjandal, in P. Bearman, Th. Bianquis, C.E. Bosworth, E. van Donzel \& W.P. Heinrichs (ed.) Encyclopedia of Islam (2 ${ }^{\text {nd }}$ edition). Leiden: Brill. Available at: https://referenceworks.brillonline.com/entries/encyclopaedia-of-islam-2/dumat-al-djandal-SIM_2153 (accessed 24 March 2020).

Wallace, C.A., S.M. Dini \& A.A. FARASANI (AL-). 1997. Explanatory notes to the geological map of the Al Jawf Quadrangle, Kingdom of Saudi Arabia Geoscience, Map GM-128C, scale 1:250,000, sheet 29D. Jiddah: Deputy Ministry for Mineral Resources, Ministry of Petroleum and Mineral Resources.

WellBRoCK, K., M. STRAUSS, C. KÜLLS \& M. GROTTKER. 2018. The oasis of Tayma, NW Arabia: transformation in terms of water management and hydrology during the last millennia, in L. Purdue, J. Charbonnier \& L. Khalidi (ed.) From refugia to oasis: living in arid environments from prehistoric times to the present day. Actes des XXXVIIIe Rencontres internationales d'Archéologie et d'Histoire d'Antibes, oct. 2017): 231-50. Antibes: APDCA.

ZARINS, J., M. IBRAHIM, D.T. POTTS \& C. EDENS. 1979. Saudi Arabian archaeological reconnaissance 1978: the preliminary report on the third phase of the Comprehensive Archaeological Survey Program-The Central Province. Atlal 3: 9-42.

ZIELHOFER, C. et al. 2018. Climate forcing and shifts in water management on the northwest Arabian Peninsula (Mid-Holocene Rasif wetlands, Saudi Arabia). Quaternary International 473: 120-40. https://doi.org/10.1016/j.quaint.2018.03.001 
Munoz, O., Cotty, M., Charloux, G., Bouchaud, C., Monchot, H., Marquaire, C., Zazzo, A., Crassard, R., Brunet, O., Boschloos, V., \& al Malki, T. (2020). Marking the sacral landscape of a north Arabian oasis: A sixthmillennium BC monumental stone platform and surrounding burials. Antiquity, 94(375), 601-621.

https://doi.org/10.15184/aqy.2020.81

\section{Figures}
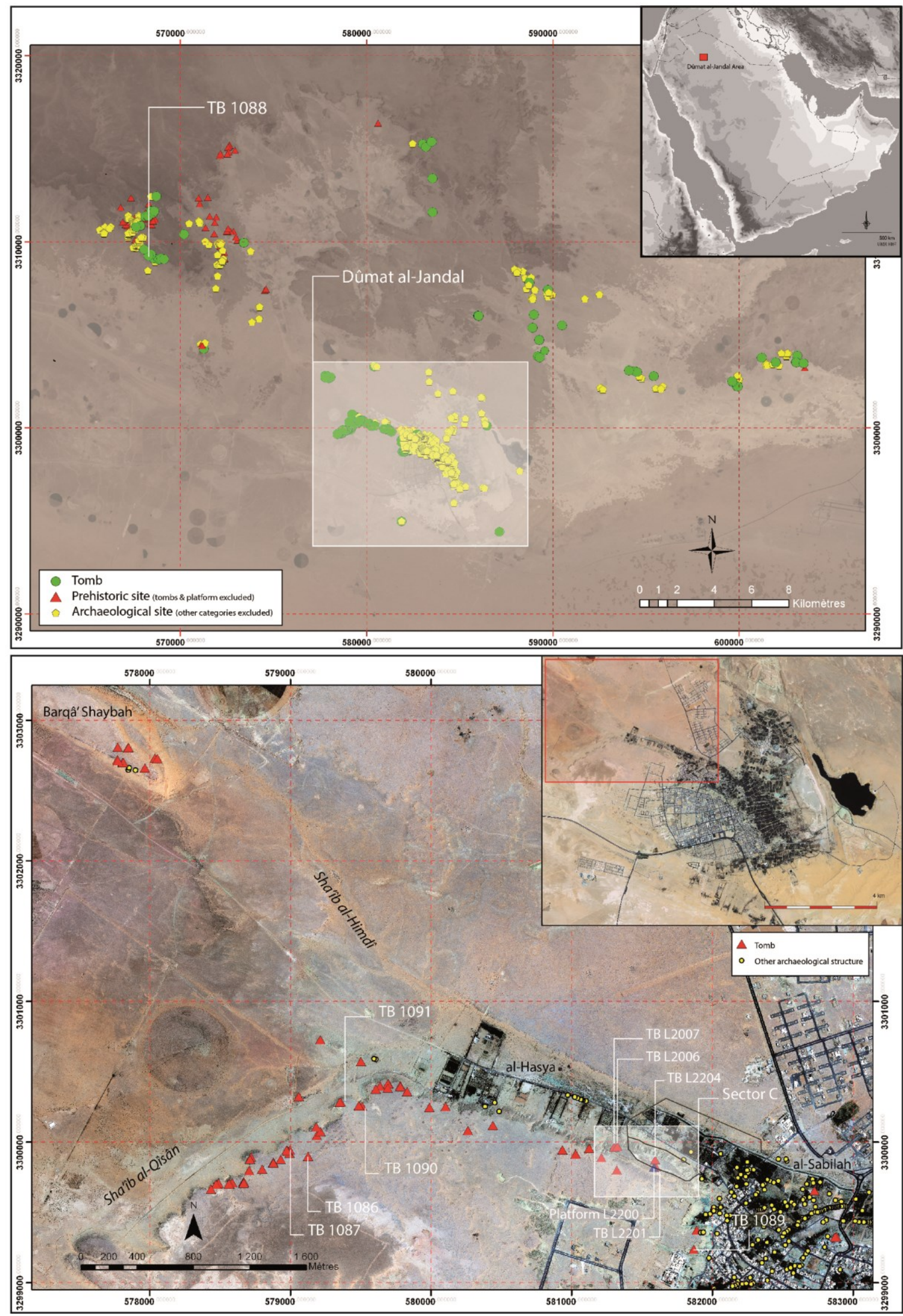

Figure 1. Map of surveys in the Dûmat al-Jandal oasis area in the northern Arabian Peninsula (top), and location of stone tombs around the platform in the western part of the oasis (bottom) ( Mission archéologique de Dûmat al-Jandal; figure by G. Charloux). 
Munoz, O., Cotty, M., Charloux, G., Bouchaud, C., Monchot, H., Marquaire, C., Zazzo, A., Crassard, R., Brunet, O., Boschloos, V., \& al Malki, T. (2020). Marking the sacral landscape of a north Arabian oasis: A sixthmillennium BC monumental stone platform and surrounding burials. Antiquity, 94(375), 601-621.

https://doi.org/10.15184/aqy.2020.81

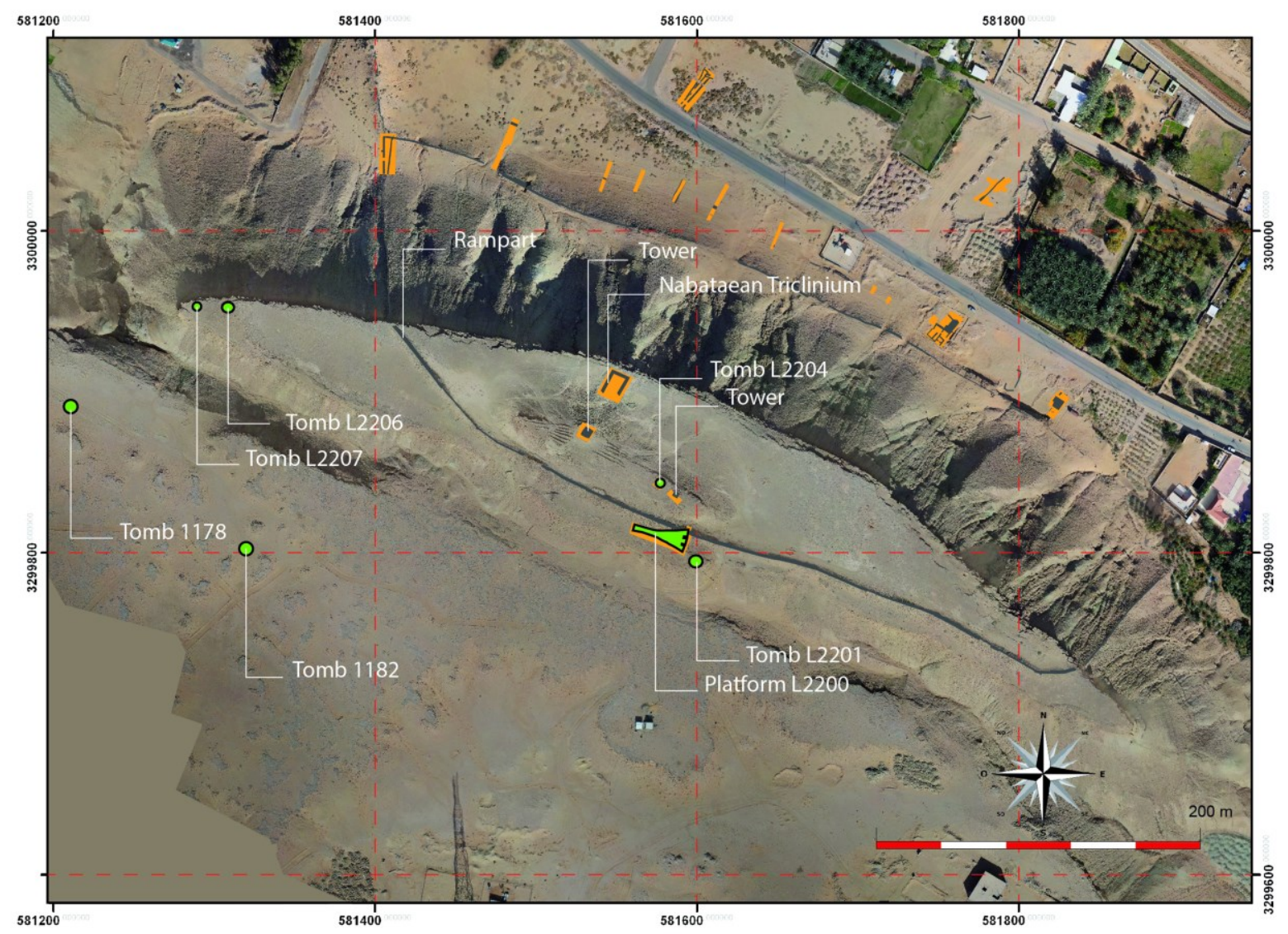

Figure 2. Satellite image of the al-Burj promontory showing the locations of archaeological structures (C) Mission archéologique de Dûmat al-Jandal; figure by G. Charloux). 
Munoz, O., Cotty, M., Charloux, G., Bouchaud, C., Monchot, H., Marquaire, C., Zazzo, A., Crassard, R., Brunet, O., Boschloos, V., \& al Malki, T. (2020). Marking the sacral landscape of a north Arabian oasis: A sixthmillennium BC monumental stone platform and surrounding burials. Antiquity, 94(375), 601-621.

https://doi.org/10.15184/aqy.2020.81
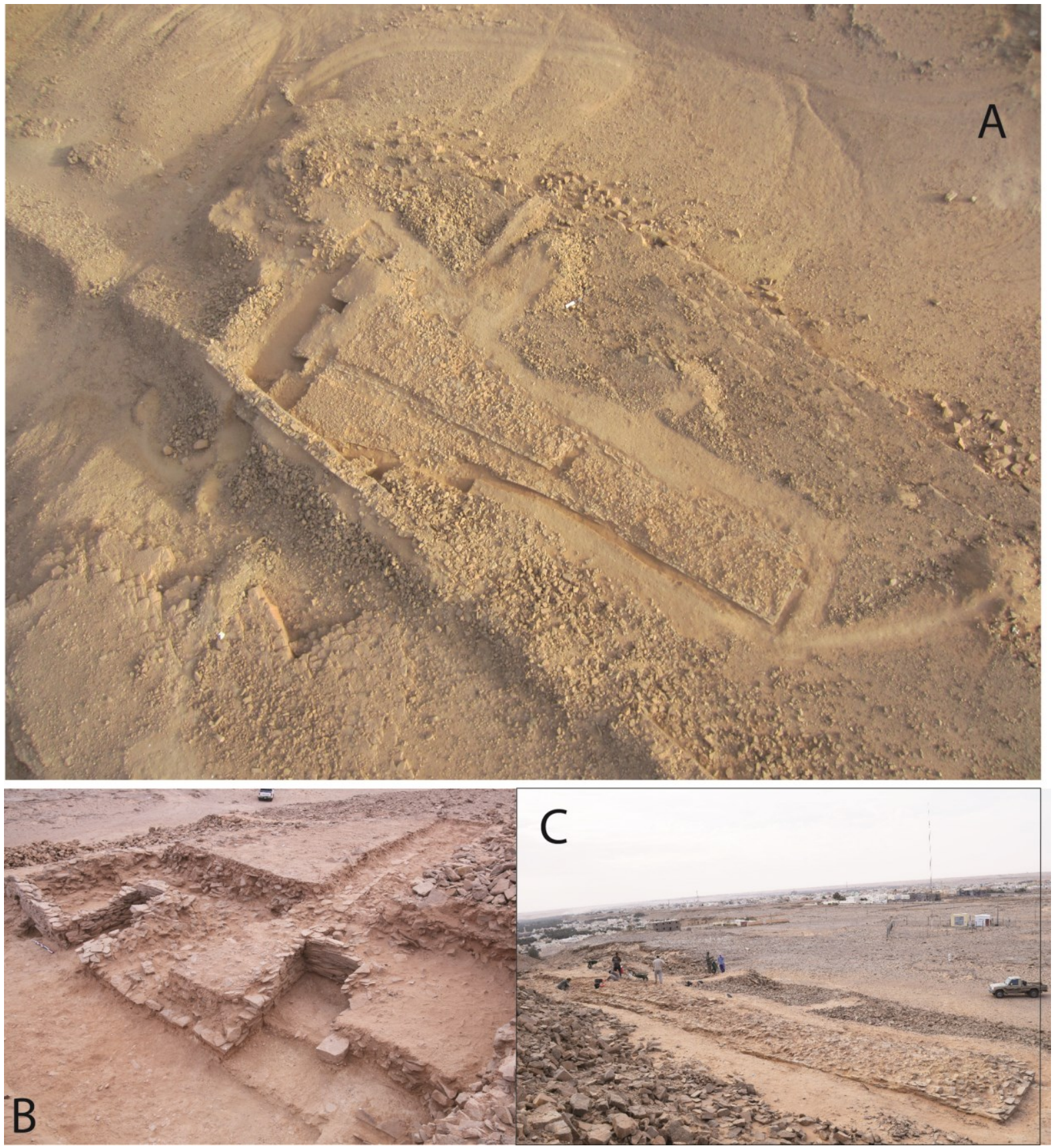

Figure 3. A) Aerial view of the platform and niches; B) eastern face of the platform with Niches 1 and 2; C) view of the platform from north (C) Mission archéologique de Dûmat al-Jandal; photographs by M. Cotty, O. Munoz and R. Schwerdtner). 
Munoz, O., Cotty, M., Charloux, G., Bouchaud, C., Monchot, H., Marquaire, C., Zazzo, A., Crassard, R., Brunet, O., Boschloos, V., \& al Malki, T. (2020). Marking the sacral landscape of a north Arabian oasis: A sixthmillennium BC monumental stone platform and surrounding burials. Antiquity, 94(375), 601-621.

\section{https://doi.org/10.15184/aqy.2020.81}

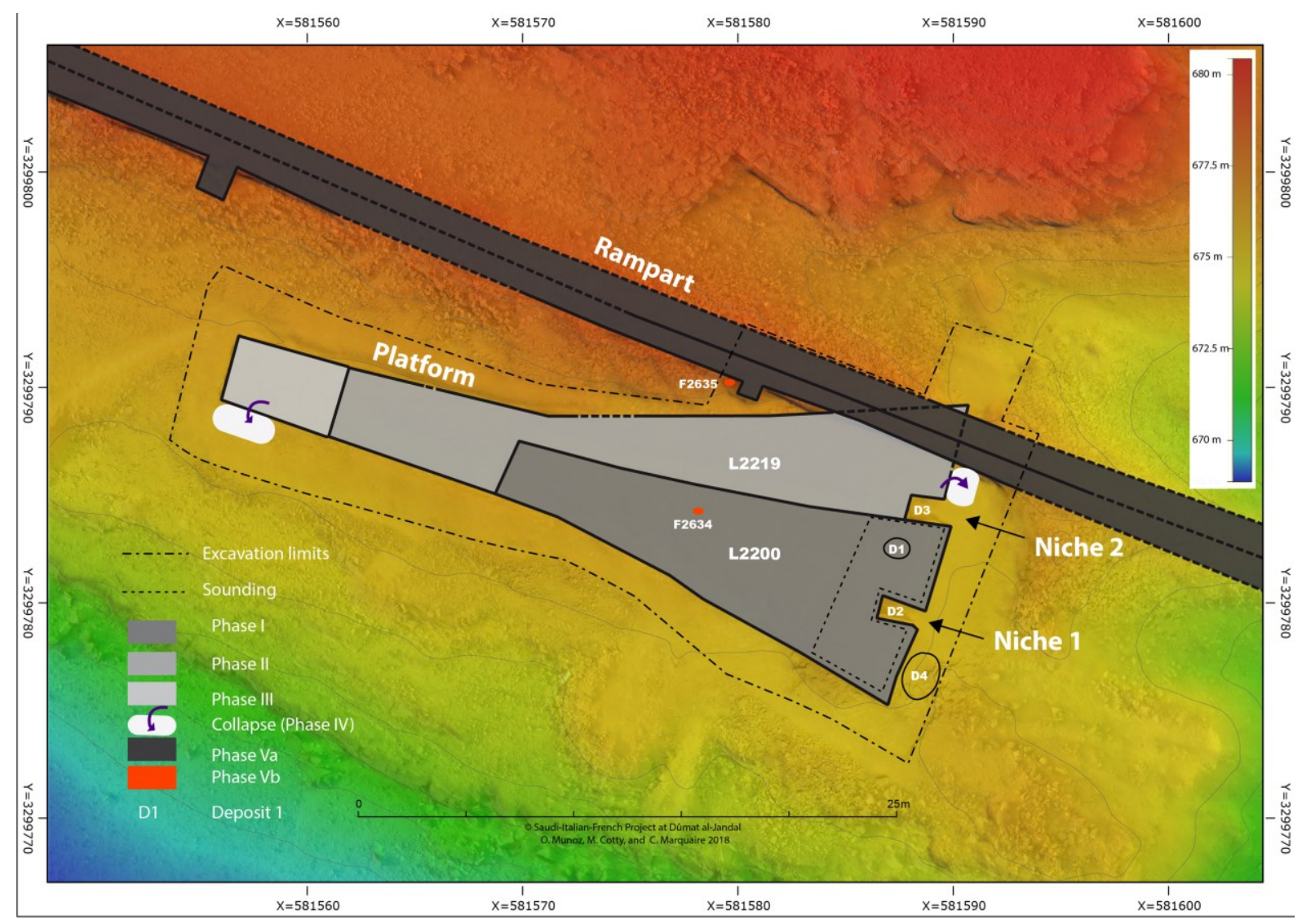

Figure 4. Plan of the platform with digital terrain model and aerial image and its construction phases, with features mentioned in the text (C) Mission archéologique de Dûmat al-Jandal; figure by O. Munoz, M. Cotty, G. Charloux, C. Marquaire and R. Schwerdtner). 
Munoz, O., Cotty, M., Charloux, G., Bouchaud, C., Monchot, H., Marquaire, C., Zazzo, A., Crassard, R., Brunet, O., Boschloos, V., \& al Malki, T. (2020). Marking the sacral landscape of a north Arabian oasis: A sixthmillennium BC monumental stone platform and surrounding burials. Antiquity, 94(375), 601-621.

https://doi.org/10.15184/aqy.2020.81

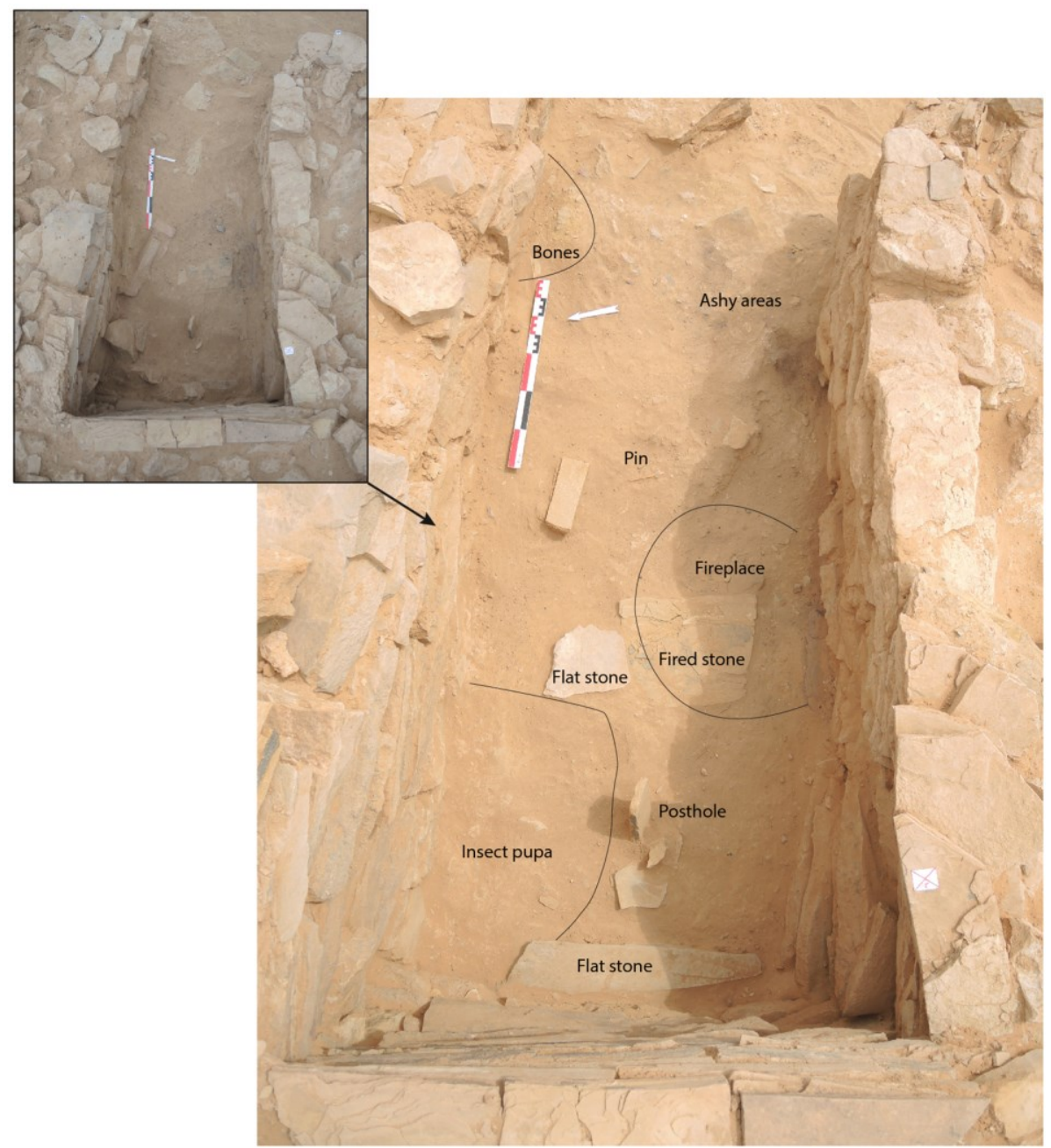

Figure 5. Views of deposit 2 (niche 1) during excavation (@) Mission archéologique de Dûmat al-Jandal; photographs by M. Cotty, O. Munoz and G. Charloux). 
Munoz, O., Cotty, M., Charloux, G., Bouchaud, C., Monchot, H., Marquaire, C., Zazzo, A., Crassard, R., Brunet, O., Boschloos, V., \& al Malki, T. (2020). Marking the sacral landscape of a north Arabian oasis: A sixthmillennium BC monumental stone platform and surrounding burials. Antiquity, 94(375), 601-621.

https://doi.org/10.15184/aqy.2020.81

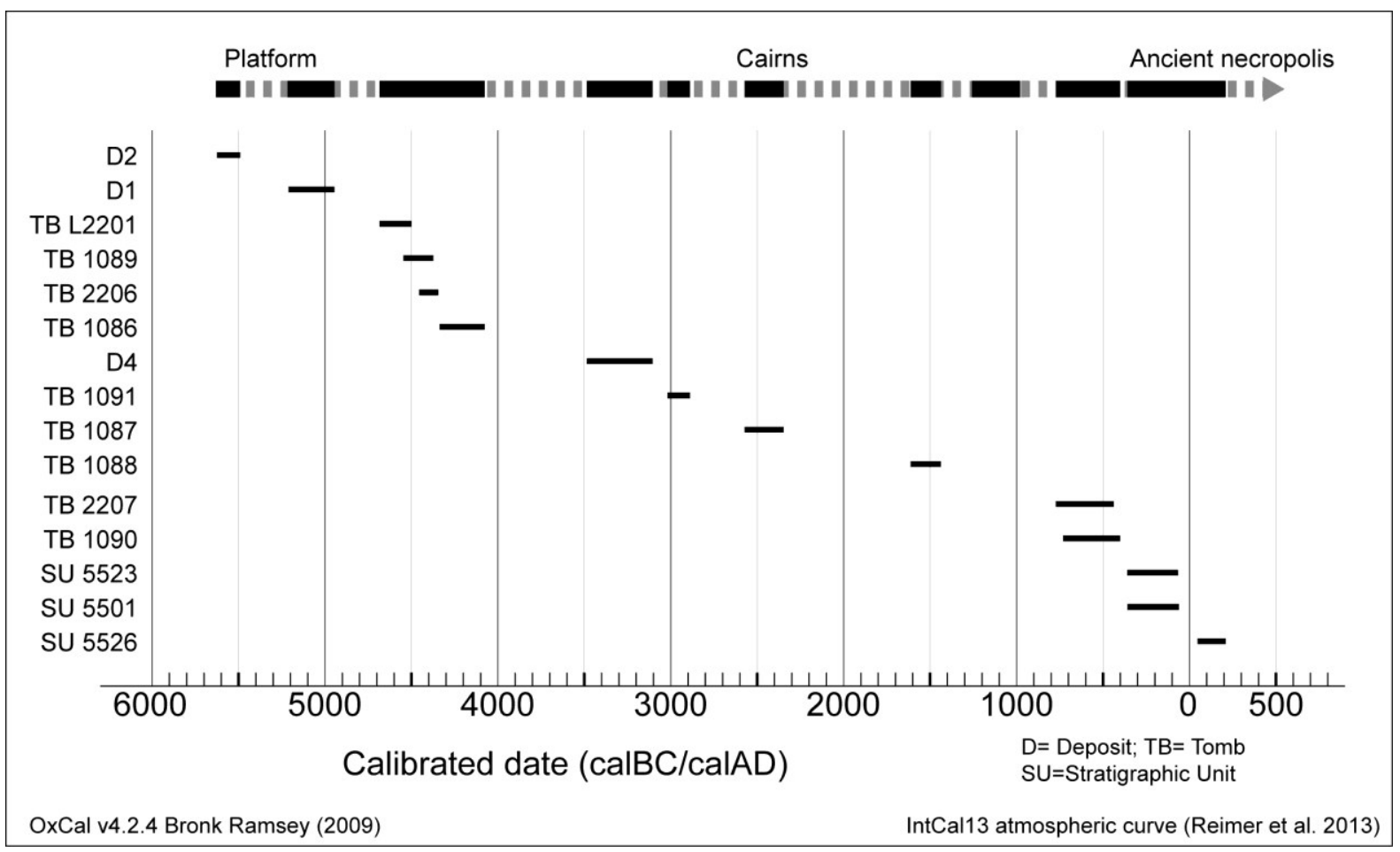

Figure 6. Radiocarbon dates and summary of the chronological sequence (C) Mission archéologique de Dûmat al-Jandal; figure by 0. Munoz). 
Munoz, O., Cotty, M., Charloux, G., Bouchaud, C., Monchot, H., Marquaire, C., Zazzo, A., Crassard, R., Brunet, O., Boschloos, V., \& al Malki, T. (2020). Marking the sacral landscape of a north Arabian oasis: A sixthmillennium BC monumental stone platform and surrounding burials. Antiquity, 94(375), 601-621.

https://doi.org/10.15184/aqy.2020.81
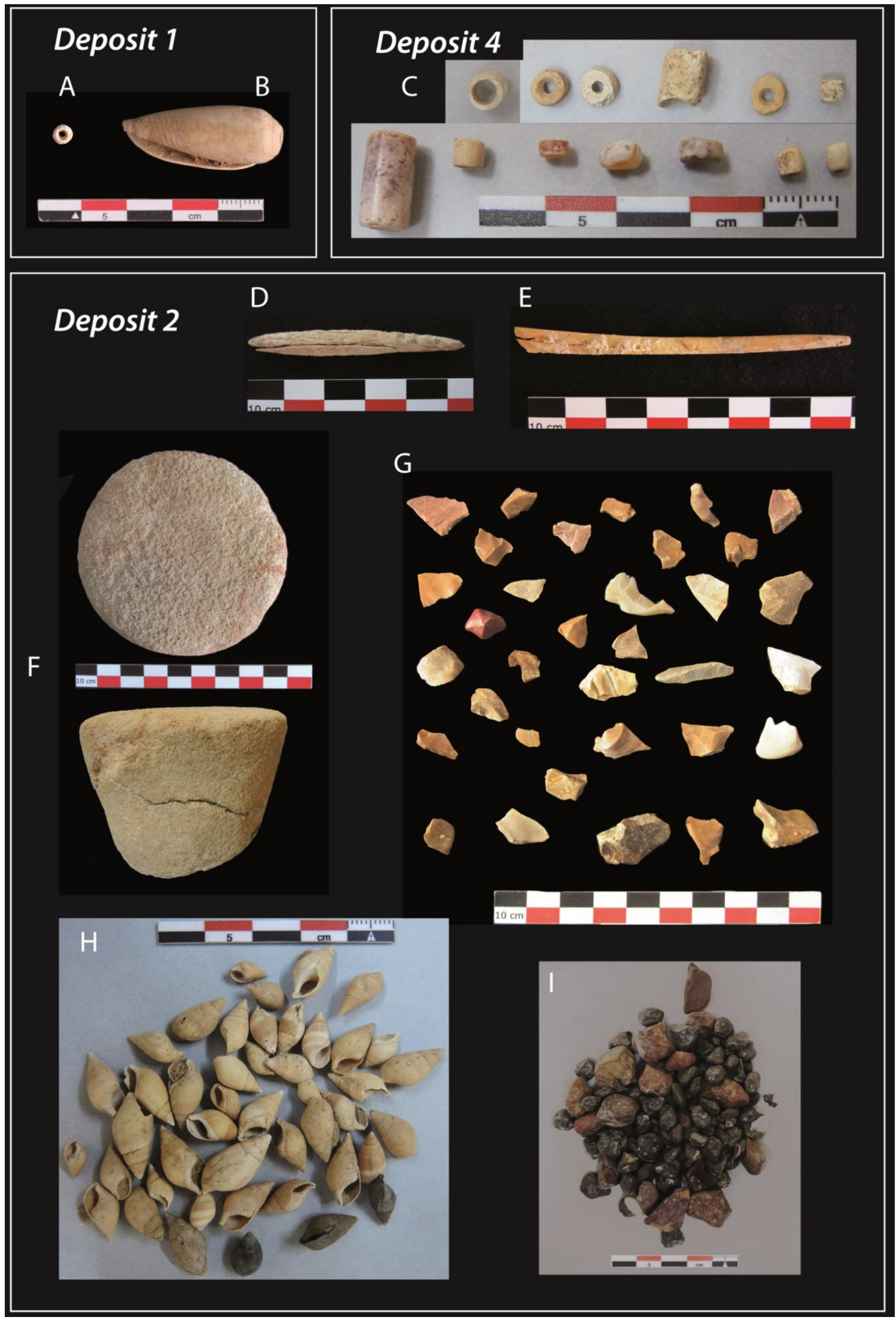

Figure 7. Artefacts from deposits 1, 2 and 4: limestone bead (A) and perforated gastropod (Pterygia crenulata) (B) from deposit 1; stone and shell beads from deposit $4(C)$; bone tools $(D-E)$, truncated conical stone $(F)$, lithics (G), terrestrial gastropods of the Melanopsidae family (H) and gravel (I) from deposit 2 (C) Mission archéologique de Dûmat al-Jandal; photographs by G. Charloux, M. Cotty and A. Chevalier). 

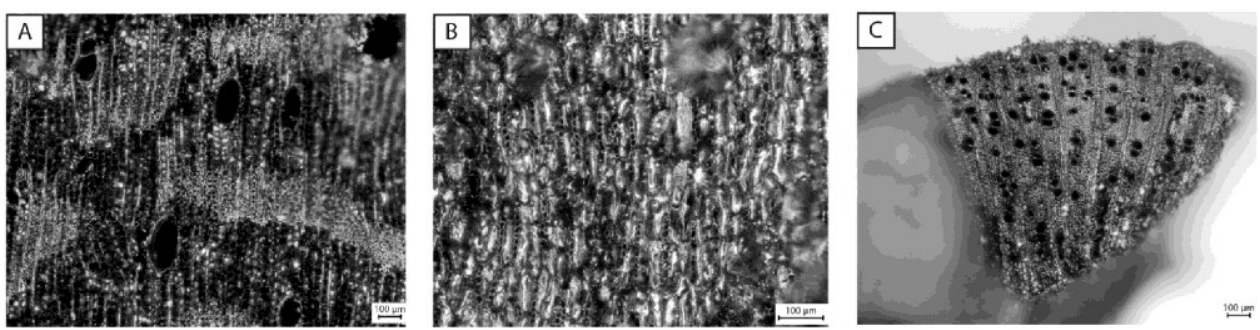

\section{SD_18_Botanical remains $(\mathrm{N}=56)$}

口Amaranthaceae

口Fadherbia albida

-Tamarix sp.

口Indeterminate
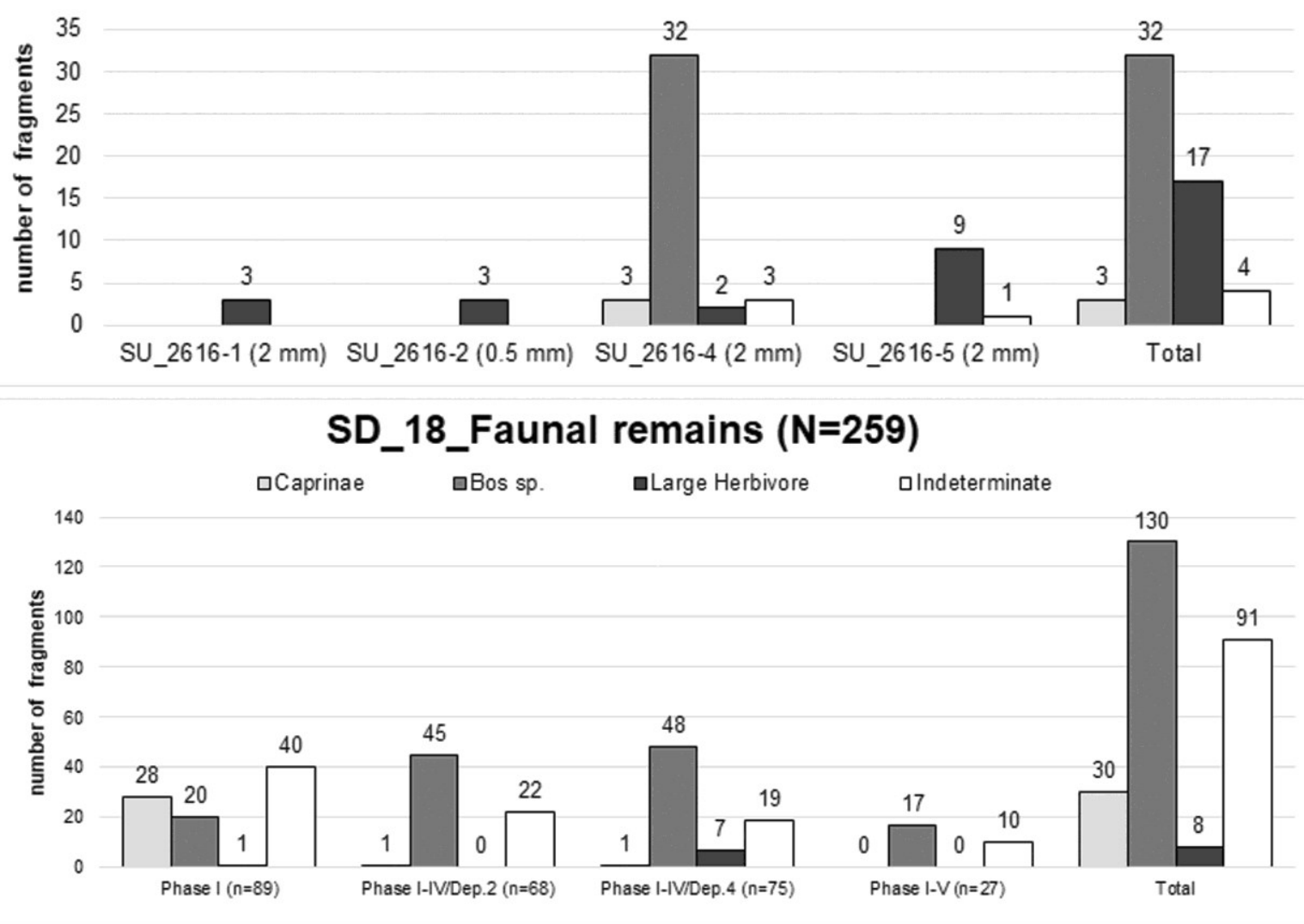

Figure 8. Top: charcoal from deposit 2, microscopic photographs $A$. Fadherbia albida, transversal section; $B$. Fadherbia albida, tangential section; $C$. Tamarix sp., transversal section (C) MADAJ; photograph by $C$. Bouchaud). Middle: results of the charcoal study of deposit 2. Bottom: faunal remains from sounding 18 (C) Mission archéologique de Dûmat al-Jandal; photograph by H. Monchot). 
Munoz, O., Cotty, M., Charloux, G., Bouchaud, C., Monchot, H., Marquaire, C., Zazzo, A., Crassard, R., Brunet, O., Boschloos, V., \& al Malki, T. (2020). Marking the sacral landscape of a north Arabian oasis: A sixthmillennium BC monumental stone platform and surrounding burials. Antiquity, 94(375), 601-621.

https://doi.org/10.15184/aqy.2020.81

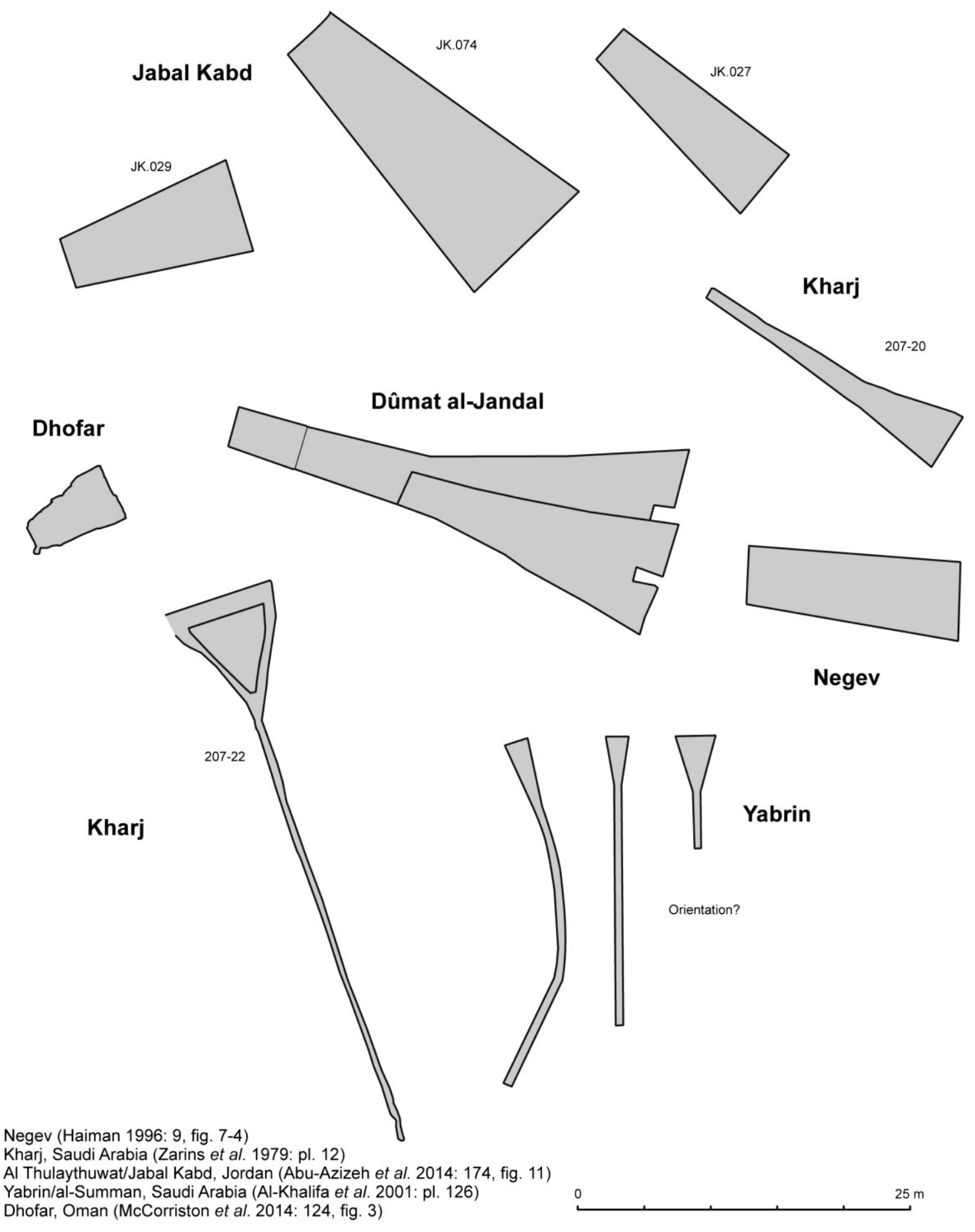

Figure 9. Schematic comparisons of known prehistoric stone platforms (C) Mission archéologique de Dûmat al-Jandal; figure by G. Charloux). 
Munoz, O., Cotty, M., Charloux, G., Bouchaud, C., Monchot, H., Marquaire, C., Zazzo, A., Crassard, R., Brunet, O., Boschloos, V., \& al Malki, T. (2020). Marking the sacral landscape of a north Arabian oasis: A sixthmillennium BC monumental stone platform and surrounding burials. Antiquity, 94(375), 601-621.

\section{https://doi.org/10.15184/aqy.2020.81}

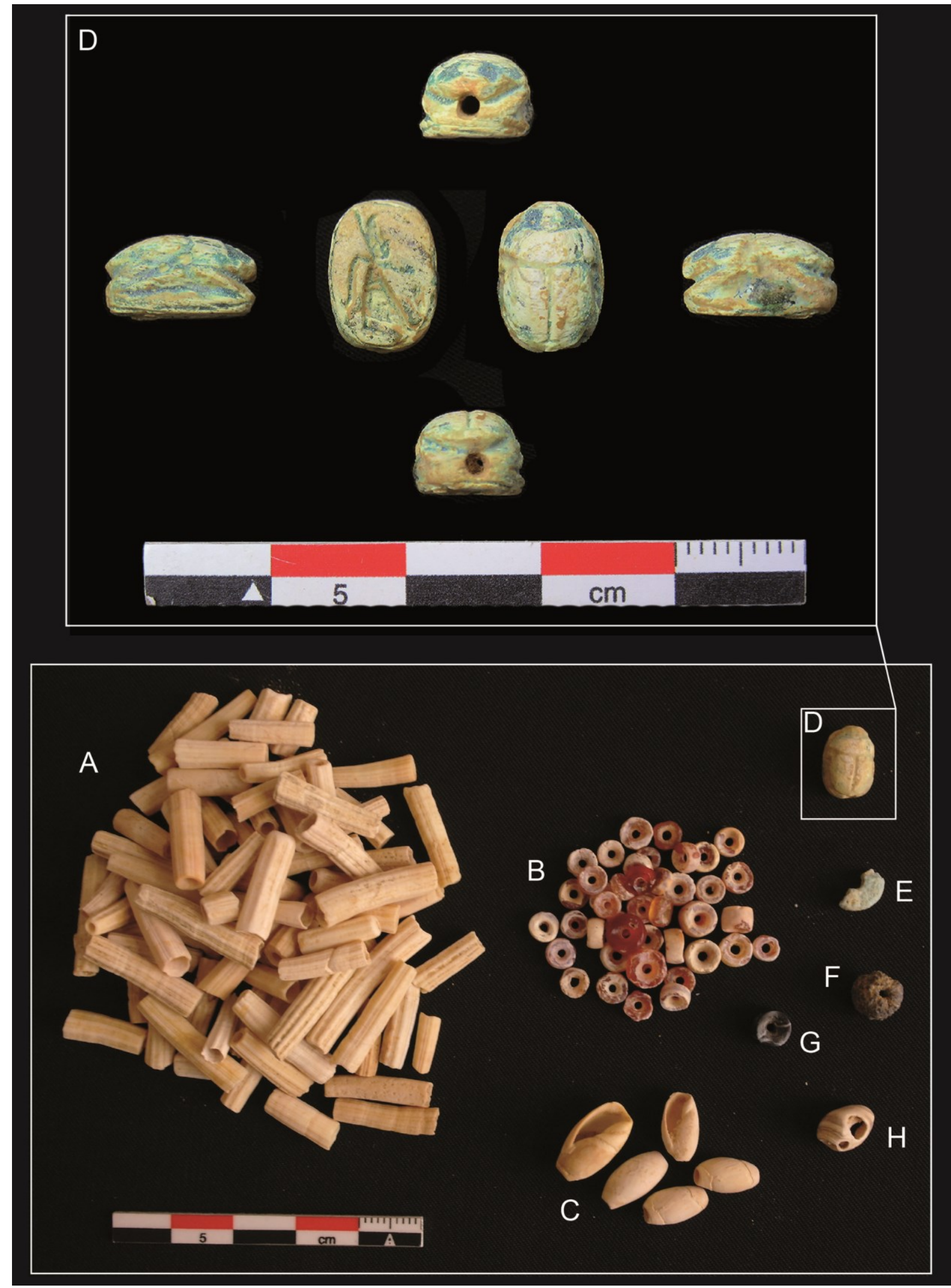

Figure 10. Artefacts from tomb L2204, SD31: A) Dentalium sp. beads; B) carnelian beads; C) perforated Pterygia crenulata shells; D) Egyptianising scarab; E) faience bead; $F-G)$ stone beads; H) perforated Engina mendicaria shell (@Mission archéologique de Dûmat al-Jandal; photographs by G. Charloux and A. Chevalier). 


\section{[Supplementary material]}

\section{Marking the sacral landscape of a north Arabian oasis: a sixth-millennium BC monumental stone platform and surrounding burials}

Olivia Munoz ${ }^{1, *}$, Marianne Cotty ${ }^{2}$, Guillaume Charloux ${ }^{3}$, Charlène Bouchaud ${ }^{4}$, Hervé Monchot $^{5}$, Céline Marquaire ${ }^{6}$, Antoine $Z_{a z z o}{ }^{4}$, Rémy Crassard ${ }^{7}$, Olivier Brunet ${ }^{8}$, Vanessa Boschloos $^{9} \&$ Thamer al-Malki ${ }^{10}$

${ }^{1}$ Centre National de la Recherche Scientifique (CNRS), Archéologie et Sciences de l'Antiquité, France

${ }^{2}$ Musée du Louvre, Département de Antiquités Orientales, France

${ }^{3}$ Centre National de la Recherche Scientifique (CNRS), Orient et Méditerranée, France

${ }^{4}$ Centre National de la Recherche Scientifique (CNRS), Muséum national d'histoire naturelle, Archéozoologie \& Archéobotanique, France

${ }^{5}$ Labex Resmed, Paris Sorbonne Universités, France

${ }^{6}$ Université Paris 1 Panthéon-Sorbonne-UFR d'Archéologie, France

${ }^{7}$ Centre National de la Recherche Scientifique (CNRS), French Center for Archaeology and Social Sciences (CEFAS), Kuwait

${ }^{8}$ Archéologie et Sciences de l'Antiquité, Nanterre, France

${ }^{9}$ Department of Archaeology, Ghent University, Belgium

${ }^{10}$ Saudi Commission for Tourism and National Heritage, Riyadh, Saudi Arabia

*Author for correspondence ( $\square$ olivia.munoz@cnrs.fr)

OSM 1. Radiocarbon dates from Dûmat al-Jandal (by O. Munoz, G. Charloux, M. Cotty \& A. Zazzo).

The radiocarbon dates discussed in this text are listed in Table S1 by area of investigation (platform, survey in the surroundings, and ancient necropolis). While the dates from the platform area and the ancient necropolis were obtained from samples collected in the excavation trenches by the archaeologists, most of the dates from the nearby cairns originate from human bone bioapatite samples (Zazzo \& Saliège 2011). They were collected during the 2015 survey in the surroundings of Dûmat by Anaïs Chevalier ( $\mathrm{PhD}$ candidate at University of Paris 1) within the framework of the Saudi-Italian-French archaeological project in Dûmat alJandal.

All the radiocarbon dates have been calibrated with Oxcal v4.2.4 (Bronk Ramsey 2009), with IntCal13 atmospheric curve (Reimer et al. 2013). The calibrated dates are given with a 95.4\% range probability $(2 \sigma)$.

Table S1. Radiocarbon dates from Dûmat al-Jandal protohistoric structures (Table by O. Munoz).

\begin{tabular}{|c|c|c|c|c|c|c|c|}
\hline LAB \# & Context & Nature & Species & \multicolumn{2}{|c|}{$\begin{array}{c}\text { Radiocarbon age } \\
\text { BP }\end{array}$} & \multicolumn{2}{|c|}{ Date, cal BC/AD (2б) } \\
\hline \multicolumn{8}{|c|}{ Platform area } \\
\hline UBA-32224 & Deposit 2[SD18_L2200_SU2616] & Charcoal & Tamaris & 6619 & \pm 37 & $5625 \mathrm{BC}$ & $5490 \mathrm{BC}$ \\
\hline SacA44356 & Deposit 1 [SD18_L2200_SU2608] & Bone (apatite) & H. Sapiens & 6110 & \pm 30 & $5210 \mathrm{BC}$ & $4940 \mathrm{BC}$ \\
\hline SacA44357 & Tomb L2201 & Bone (apatite) & H. Sapiens & 5735 & \pm 30 & $4685 \mathrm{BC}$ & $4500 \mathrm{BC}$ \\
\hline SacA44355 & Deposit 4 [SD18_L2200_SU2605] & Bone (apatite) & H. Sapiens & 4555 & \pm 30 & $3485 \mathrm{BC}$ & $3100 \mathrm{BC}$ \\
\hline UBA33305 & Fireplace [SD18_L2200_F2635] & Charcoal & - & 2386 & \pm 32 & $730 \mathrm{BC}$ & $395 \mathrm{BC}$ \\
\hline UBA33306 & Tomb L2204 [SD31_SU2910] & Charcoal & - & 2026 & \pm 32 & $155 \mathrm{BC}$ & $\mathrm{AD} 55$ \\
\hline \multicolumn{8}{|c|}{ Cairns (survey) } \\
\hline SacA44370 & Tomb 1089 & Bone (apatite) & H. Sapiens & 5645 & \pm 30 & $4545 \mathrm{BC}$ & $4370 \mathrm{BC}$ \\
\hline SacA44358 & Tomb L2206 & Bone (apatite) & H. Sapiens & 5545 & \pm 30 & $4450 \mathrm{BC}$ & $4340 \mathrm{BC}$ \\
\hline SacA44367 & Tomb 1086 & Bone (apatite) & H. Sapiens & 5385 & \pm 30 & $4335 \mathrm{BC}$ & $4075 \mathrm{BC}$ \\
\hline
\end{tabular}


Munoz, O., Cotty, M., Charloux, G., Bouchaud, C., Monchot, H., Marquaire, C., Zazzo, A., Crassard, R., Brunet, O., Boschloos, V., \& al Malki, T. (2020). Marking the sacral landscape of a north Arabian oasis: A sixthmillennium BC monumental stone platform and surrounding burials. Antiquity, 94(375), 601-621.

https://doi.org/10.15184/aqy.2020.81

\begin{tabular}{|l|l|l|l|l|l|c|c|}
\hline SacA44378 & Tomb 1091 & Bone (apatite) & H. Sapiens & 4310 & \pm 35 & 3020 BC & 2880 BC \\
\hline SacA44368 & Tomb 1087 & Bone (apatite) & H. Sapiens & 3960 & \pm 30 & 2575 BC & 2345 BC \\
\hline SacA44369 & Tomb 1088 & Bone (apatite) & H. Sapiens & 3235 & \pm 30 & 1610 BC & 1435 BC \\
\hline SacA44359 & Tomb L2207 & Bone (apatite) & H. Sapiens & 2470 & \pm 30 & 770 BC & 430 BC \\
\hline SacA44371 & Tomb 1090 & Bone (apatite) & H. Sapiens & 2390 & \pm 30 & 730 BC & 395 BC \\
\hline Ancient necropolis & $\begin{array}{l}\text { Burned bone } \\
\text { (apatite) }\end{array}$ & H. Sapiens & 2150 & \pm 30 & 360 BC & 60 BC \\
\hline SacA44361 & SectD_Trench10_SU5523 & Bone (apatite) & H. Sapiens & 2145 & \pm 30 & 355 BC & 55 BC \\
\hline SacA44360 & SectD_Trench2_SU5501 & Bone (apatite) & H. Sapiens & 1895 & \pm 30 & AD 50 & AD 215 \\
\hline SacA44366 & SectD_Trench10_SU5526 &
\end{tabular}

OSM 2. Notes on the human bones from the Deposits 1 and 4 (by O. Munoz).

Deposit 1 consists of two concentrations of human bones lying horizontally in the stone filling of the platform, about $0.80 \mathrm{~m}$ from the bedrock. The first concentration is mainly represented by a secondary deposition of five long bones diaphysis (femur, radius and three portions of indeterminate long bones), as well as a skull cap fragment about $100 \mathrm{~mm}$ in diameter, a femur head fragment, a vertebral arch fragment, and a cuneiform fragment.

A few dozen centimeters further north, at the same altitude, few fragments of indeterminate long bones were grouped with altered remains of a coxal bone.

Unfortunately, the poor state of conservation of the human remains limits their proper identification. At least one individual is represented, and the format of the bones found corresponds to an adult skeleton. However, the absence of the extremities of the long bones does not make it possible to ascertain the state of synostosis. It can therefore only be stated that at least one individual over 15 years of age is represented.

Some long bones had axial deformations due to the weight of the stones and sediments covering them. This suggests that they were still "fresh" (containing collagen) when they were buried, because in the opposite case (totally dry bones), they would have been fractured.

In Deposit 4, 2647 bone fragments have been collected, from which 450 have been identified. The remaining 2197 were too fragmentary to be precisely determined (e.g. small fragments or splinters from a skull(s), long bone diaphysis, or spongious bone). At least five individuals are represented in this assemblage including one subadult (1-4 years old), and four adults.

The position of the bones and artefacts, which rested at varying depths in the sediment, indicate a secondary deposit and probable disturbances. Although the provenience of the primary deposit is unknown, we can assume that it comes from a funerary structure in the vicinity, as suggested by the presence of small bones and pearls, and the presence of disrupted stone tombs in the area (e.g. Tomb L2201; Figure 2). Finally, the state of preservation of the bones, rather good despite their fragmentation, suggests that they have not been exposed to climatic agents for long periods (limited weathering). Therefore, it is unlikely that these funerary remains would have been disposed of in front of the eastern wall of the platform.

OSM 3. Tables of the archaeobotanical and faunal studies (by C. Bouchaud \& $\mathbf{H}$. Monchot).

Table S2. Identification of the archaeobotanical remains found in the Niche 1 (SU 2616) of the platform (table by C. Bouchaud).

\begin{tabular}{|l|c|c|c|c|c|}
\hline Fraction & Amaranthaceae & Fadherbia albida & Tamarix sp. & Indeterminate & Total \\
\hline SU_2616-1 $(2 \mathrm{~mm})$ & & & 3 & & 3 \\
\hline SU_2616-2 $(0.5 \mathrm{~mm})$ & & & 3 & & 3 \\
\hline SU_2616-4 $(2 \mathrm{~mm})$ & 3 & 32 & 2 & 3 & 40 \\
\hline SU_2616-5 $(2 \mathrm{~mm})$ & & & 9 & 1 & 10 \\
\hline
\end{tabular}


Munoz, O., Cotty, M., Charloux, G., Bouchaud, C., Monchot, H., Marquaire, C., Zazzo, A., Crassard, R., Brunet, O., Boschloos, V., \& al Malki, T. (2020). Marking the sacral landscape of a north Arabian oasis: A sixthmillennium BC monumental stone platform and surrounding burials. Antiquity, 94(375), 601-621.

https://doi.org/10.15184/aqy.2020.81

\begin{tabular}{|l|l|l|l|l|l|}
\hline Total & 3 & 32 & 17 & 4 & 56 \\
\hline
\end{tabular}

Table S3. Identification of the faunal remains found in the platform (table by H. Monchot).

\begin{tabular}{|l|c|c|c|c|c|}
\hline Phase & Caprinae & Bos & Large herbivore & Indeterminate & Total \\
\hline Phase I $(\mathrm{n}=89)$ & 28 & 20 & 1 & 40 & 89 \\
\hline Phase I-IV/Dep.2 $(\mathrm{n}=32)$ & 1 & 9 & 0 & 22 & 32 \\
\hline Phase I-IV/Dep.4 $(\mathrm{n}=72)$ & 1 & 46 & 6 & 19 & 72 \\
\hline Phase I-V (n=27) & 0 & 17 & 0 & 10 & 27 \\
\hline Total & 30 & 92 & 7 & 91 & \\
\hline
\end{tabular}

OSM 4. Notes on the beads found in Deposit 4 and SD31 (L. 2204) (by O. Brunet).

Thirteen beads mixed with the human remains were recovered from Deposit 4: two cylindrical shell beads, three cylindrical stone beads, three flat beads of whitish stone, and five carnelian beads.

Although the materials and typologies of the beads do not refer to a precise chronological period, the presence of chalcedony (worked and unworked) is particularly interesting, as it hints at mid- to long-distance contacts from the Chalcolithic to the first millennium BC.

Chalcedony deposits, which carnelian belongs to, seem to be present in western Saudi Arabia in small quantity, as stated by M. Tosi (Tosi 1980). Flint drills discovered in Rajajil, 32km from Dûmat, suggest local working of hard stones in the area (Adams et al. 1977: P1. 15, $\mathrm{n}^{\circ}$ 17, 28, 29; Eichmann et al. 2006: 101). Some $270 \mathrm{~km}$ south-west, at Taymā', a carnelian bead workshop was found (Bawden et al. 1980; Miller 1984; Hausleiter 2013; Al-Ghabban et al. 2010: 250-51). Beads found there show similar sizes and the same technological know-how. This could suggest a local origin for carnelian products. For later contexts, however, an Egyptian origin of carnelian beads can be assumed (Aston et al. 2000: 26-27; Bloxam 2006), and is supported by the artefacts discovered during the excavation of a looted tomb located at $20 \mathrm{~m}$ of the platform (SD31, TB L2204, excavated by Anaïs Chevalier (PhD candidate at University Paris 1; Figure 2). There, several carnelian beads were found in association with Dentalium and Pterygia crenulata shells, whose species may be found in the Red sea (Bar Yosef 2005), as well as an Egyptianized scarab (see OSM 5), and a faience bead with a light green superficial glaze (Figure 9). It is well known that Egypt was one of the main areas of development of this glazing technique (Caubet \& Pierrat-Bonnefois 2005). Radiocarbon dating from this tomb indicates a much more recent date than the platform and the Deposit 4 (155 cal. BC-AD 55; Table S1). In Taymā', several objects with Egyptian influence were also discovered (see al-Ghabban et al. 2010: 231; Hausleiter 2013).

Therefore, if contacts between North-Western Arabia and Egypt are well attested for the first millennium $\mathrm{BC}$, more investigation will be needed to prove such contacts during the protohistoric period.

\section{OSM 5. Notes on scarab 0.2910-1 from a looted tomb (SD31, TBL2204) (by V. Boschloos).}

This scarab-shaped seal-amulet is made of steatite and traces of blue glaze remain inside the engravings. The object is pierced longitudinally and measures $12 \times 8 \times 7 \mathrm{~mm}$. Its base is engraved with a stylized representation of a human figure (most probably male) facing right. While its right arm hangs down next to the body, its left arm is raised in front of the figure. He wears a long skirt, decorated with crossing lines, either indicating decorative patterns or folds in the fabric. A vertical incision is discernible in the lower right part, connected to the front of the skirt. On the edges, sections of a line surrounding the entire design are still visible.

The figure most likely represents an Egyptian Pharaoh, as the contours of the headdress indicate that he is wearing the Pschent or the Egyptian Double Crown. He is shown in a standing pose, 
Munoz, O., Cotty, M., Charloux, G., Bouchaud, C., Monchot, H., Marquaire, C., Zazzo, A., Crassard, R., Brunet, O., Boschloos, V., \& al Malki, T. (2020). Marking the sacral landscape of a north Arabian oasis: A sixthmillennium BC monumental stone platform and surrounding burials. Antiquity, 94(375), 601-621.

https://doi.org/10.15184/aqy.2020.81

with one foot visible below. Depictions of a single royal figure as a main motif appear on scarabs as early as the seventeenth-sixteenth century BC (e.g. Ben-Tor 2007: pl. 63, n 6-7 \& 20 , pl. $\left.102, n^{\circ} 14 \& 25\right)$, but they are particularly popular during the Egyptian New Kingdom (eighteenth-twentieth dynasties, c. 1550-1075 BCE), especially during the early to mideighteenth dynasty, and between the mid-nineteenth and mid-twentieth dynasty (Wiese 1990: 11). The image of the standing pharaoh is also occasionally engraved on Egyptian scarabs at the beginning of the Late Period (twenty-sixth dynasty, c. 664-525 BCE) as a result of an 'archaising' trend in that period, for example, on a scarab attributed to the twenty-sixth dynasty found at Tel Dan: Keel (2010: 390-91, n²1) and parallels cited there.

However, the great majority of these scarabs show the king holding the hqa sceptre, the was sceptre, and/or the flagellum, wearing the Khepresh or Egyptian Blue Crown, in his ceremonial function as divine leader. One variation of the theme is the standing royal figure with a cobra or uraeus, which highlights the protective and apotropaic power of the royal figure, and consequently of the seal-amulet. Either single or in pairs, the cobra is placed in association with the king (next to or below his feet), or is in direct contact with the king, attached to his skirt (Wiese 1990: 18-24, see p. 23 for the interpretation of the cobra attachments as belts in the royal dress).

The latter seems to be the case on the scarab from Dûmat al-Jandal. Such cobras are protruding outwards from one or both sides of the king's skirt, hanging down from it and looking outwards, in this case from the front. However, the best parallels for the present scarab depict a kneeling pharaoh with a uraeus attached to his skirt (kept in the Egyptian Museum in Cairo, see Wiese 1990: $20 \mathrm{n}^{\circ} 231-233$, abb. 32). Most interestingly, the standing or kneeling pharaoh with uraei is most frequently attested on scarabs dated to the Ramesside Period (e.g. Teeter 2003: ${ }^{\circ} 11$ ). Even though only a few bear royal names that would allow linking them to particular kings or dynasties, the style of their engravings and the morphology of the scarabs suggest that this iconographic sujet does not appear before the nineteenth dynasty (Wiese 1990: 20).

Furthermore, the morphology of this particular scarab does not exclude a date as early as the New Kingdom (for typological characteristics see Keel 1995: 50-51). When seen from above, the legs surround the beetle like a frame, and small v-shaped notches are engraved on the humeral callosities (the 'shoulders' of the beetle). The legs are carved out and may have been decorated with parallel hatching. Unfortunately, the state of preservation of the scarab's surface does not allow discerning details on the scarab's head and legs.

In conclusion, I should emphasize that this is one of the few scarabs from controlled excavations in Saudi Arabia (see also concluding remarks in Boschloos \& Akkermans forthcoming). Less than a dozen scarabs have surfaced in the Arabian Peninsula, and all were found along the coast of the Arabian Gulf and in Southern Arabia. The presence of this scarab at Dûmat al-Jandal, in the Northwest of Saudi Arabia, is currently an isolated find. Contrary to other finds on the peninsula, it probably arrived by land. The presence of Egyptian-style objects at the site is explained by its proximity to the Sinai and to the Southern Levant, where large numbers of Egyptian and Egyptianising scarabs circulated from the early second millennium $\mathrm{BC}$ to at least the mid-first millennium $\mathrm{BC}$.

\section{References}

ADAMS, R., P.J. PARR, M. IBRAHIM \& A.S. MUGHANNUM. 1977. Saudi Arabian archaeological reconnaissance1976: preliminary report on the first phase of the comprehensive archaeological survey program. Atlal 1: 21-40.

Al-Ghabban, A.I., B. Andre-Salvini, F. Demange, C. Juvin \& M. Cotty. 2010. Routes d'Arabie: archéologie et histoire du royaume d'Arabie Saoudite, catalogue de l'expostion. Paris: Musée du Louvre=. 
Munoz, O., Cotty, M., Charloux, G., Bouchaud, C., Monchot, H., Marquaire, C., Zazzo, A., Crassard, R., Brunet, O., Boschloos, V., \& al Malki, T. (2020). Marking the sacral landscape of a north Arabian oasis: A sixthmillennium BC monumental stone platform and surrounding burials. Antiquity, 94(375), 601-621.

https://doi.org/10.15184/aqy.2020.81

Aston, B.G., J. HARRell \& I. Shaw. 2000. Stone, in I. Shaw \& P.T. Nicholson (ed.) Ancient Egyptian materials and technology: 5-77. Cambridge: Cambridge University Press.

BAR-Yosef, D.E. 2005. The exploitation of shells as beads in the Palaeolithic and Neolithic of the Levant. Paléorient 31: 176-85. https://doi.org/10.3406/paleo.2005.4796

BAWDEN, G., C. EDENS \& R. MiLLER. 1980. The archaeological resources of ancient Taymâ: preliminary investigations at Taymâ. Atlal 4: 69-106.

BEN-TOR, D. 2007. Scarabs, chronology, and interconnections: Egypt and Palestine in the Second Intermediate Period (Series Archaeologica 27) Freiburg \& Göttingen: Orbis Biblicus et Orientalis.

BloXAM, E. 2006. Miners and mistresses: Middle Kingdom mining on the margins. Journal of Social Archaeololgy 6: 277-303. https://doi.org/10.1177/1469605306064244

Boschloos V. \& P.M.M.G. AkKermans. Forthcoming 2020. From a Land Far Far Away: Egyptian(Ising) Amulets from Jebel Qurma, North-Eastern Jordan. Studies in History and Archaeology of Jordan 14. Amman: Department of Antiquities of Jordan.

BRONK RAMSEY, C. 2009. Bayesian analysis of radiocarbon dates. Radiocarbon 51: 337-60. https://doi.org/10.1017/S0033822200033865

CAubet, A. \& G. Pierrat-Bonnefois. 2005. Faïences: faïences de l'Antiquité. De l'Egypte à l'Iran. Paris: Musée du Louvre.

Eichmann, R., A. Hausleiter, M.H. AL-NAJEM \& S.F. AL-SAID. 2006. Tayma, spring 2004: report on the Joint Saudi Arabian-German Archaeological Project. Atlal 19: 91-116.

HAuSLEITER, A. 2013. Tayma (north-west Arabia): Saudi-German Joint Archaeological Project. Bulletin of the British Foundation for the Study of Arabia 18: 35-36.

KeEL, O. 1995. Corpus der Stempelsiegel-Amulette aus Palästina/Israel. Einleitung, Volume 10 (Orbis Biblius et Orientalis-Series Archaeologica 10). Freiburg \& Göttingen: Orbis Biblius et Orientalis.

- 2010. Corpus der Stempelsiegelamulette aus Palästina/Israel. Katalog Band II: Von Bahan bis Tel Eton (Orbis Biblius et Orientalis-Series Archaeologica 29). Freiburg \& Göttingen: Orbis Biblius et Orientalis.

MiLLER, R. 1984. Flakes stone industries of Arabia and the Gulf from the Late Iron Age to early Islamic times, in R. Boucharlat \& J.-F. Salles (ed.) Arabie orientale: Mésopotamie et Iran méridional de l'âge du Fer au début de la période Islamique: 145-50. Paris: Recherches sur les Civilisations.

REIMER, P.J. et al. 2013. IntCal13 and Marine13 radiocarbon age calibration curves 0-50 000 years cal BP. Radiocarbon 55: 1869-87. https://doi.org/10.2458/azu_js_rc.55.16947

TEETER, E. 2003. Scarabs, scaraboids, seals and seal impressions from Medinet Habu (Oriental Institute Publications 118). Chicago (IL): Oriental Institute.

Tosi, M. 1980. Karneol. Reallexikon der Assyriologie 5: 448-52.

WIESE, A. 1990. Zum Bild des Konigs auf Ägyptischen Siegelamuletten (Orbis Biblicus et Orientalis 96). Freiburg \& Göttingen: Orbis Biblicus et Orientalis.

ZAZZO, A. \& SALIEGE, J.-F. 2011. Radiocarbon dating of biological apatites: a review. Palaeogeography, Palaeoclimatology, Palaeoecology 310: 52-61. https://doi.org/10.1016/j.palaeo.2010.12.004 